\title{
A revision of the genus Pochytoides Berland \& Millot, 1941 (Araneae: Salticidae), with descriptions of six new species
}

\author{
Wanda WESOLOWSKA \\ Department of Biodiversity and Evolutionary Taxonomy, Wrocław University, \\ Przybyszewskiego 65, 51-148 Wrocław, Poland. \\ Email: helena.wesolowska@uwr.edu.pl \\ urn:1sid:zoobank.org:author:E362DE8A-ECB7-4C6E-B373-9E1821D214F7
}

\begin{abstract}
The concept of the jumping spider genus Pochytoides Berland \& Millot, 1941 is reviewed, based on the examination of described and undescribed species. Pochytoides is elevated from the subgeneric to the generic rank and a short diagnosis and description of the genus are presented. Redescriptions or descriptions of all species are provided together with a key to the species. Two new combinations are proposed: Pochytoides perezi (Berland \& Millot, 1941) comb. nov. and P. poissoni (Berland \& Millot, 1941) comb. nov. (both from Pochyta). Pochyta remyi Berland \& Millot, 1941 originally placed in the subgenus Pochytoides is excluded; new combination Thiratoscirtus remyi (Berland \& Millot, 1941) comb. nov. is proposed for it (but its generic status is uncertain). Six new species are described: Pochytoides monticola sp. nov., P. obstipa sp. nov., P. lamottei sp. nov., P. patellaris sp. nov., P. securis sp. nov. and $P$. spiniger sp. nov. The genus has a West African distribution.
\end{abstract}

Key words. New species, new combinations, biodiversity, Nimba Mts, afrotropics.

Wesołowska W. 2018. A revision of the genus Pochytoides Berland \& Millot, 1941 (Araneae: Salticidae), with descriptions of six new species. European Journal of Taxonomy 418: 1-26.

https://doi.org/10.582/ejt.2018.418

\section{Introduction}

Pochytoides was originally designated as a subgenus of Pochyta Simon, 1901 by Berland \& Millot (1941) for three species from Guinea.

It is proposed that Pochytoides be removed from Pochyta and elevated to full generic rank based on morphological evidence. This paper presents redescriptions of the species of this genus as well as descriptions of six new related species from the Nimba Mountains (W Africa). Members of Pochytoides are small jumping spiders, belonging to the subtribe Thiratoscirtina (Bodner \& Maddison 2012) and they share features with other members of this group. These include a high cephalothorax, sloping abruptly in its posterior part, very long ventral spines on the tibia and metatarsus of the first leg, relatively large anterior median eyes, the eye field wider anteriorly and the female palp with a tarsal spine. The general 
pattern of the genitalic structure in Pochytoides is unique and clearly separates the genus from the other thiratoscirtine genera (see diagnosis of the genus below).

\title{
Material and methods
}

All spiders considered here have been collected in Guinea. Three species, P. perezi comb. nov., P. poissoni comb. nov. and P. remyi, were described by Berland \& Millot (1941) and were collected by J. Millot in 1937 in the vicinity of Macenta (Guinea). Types of these species are kept in the collection of MNHN.

The specimens from the Nimba Mountains were collected during the expeditions led by M. Lamotte (with collaborators) in the years 1942, 1951, 1956 and in 1961. A substantial part of this collection is kept in MNHN and has already been examined by Rollard \& Wesołowska (2002). Another part of the material, used in the present study, is deposited in the NHM and has not been studied so far. Unfortunately, the majority of labels do not contain precise data on localities and dates, referring only to the 'Nimba Mts'. Additional abundant material was collected by Arnaud Henrard (with associates) during expeditions to the Nimba Mountains in 2011 and 2012. These newly collected specimens were deposited in the MRAC.

Six new species described in this article come from the latter two collections and their type specimens are deposited in NHM and MRAC.

Male-female matching was based on the co-occurrence of specimens, but in some cases more than one species was found in a single vial. Comparison of the embolus length to the length of the epigynal copulatory ducts was helpful in these cases, but it is still possible, that the matched sexes actually do not belong to the same species.

The specimens are preserved in $70 \%$ ethanol and were examined in ethanol. Some of the studied specimens are heavily bleached and the colours given in the descriptions may differ from those in the living spiders. The drawings were made with the aid of a reticular eyepiece attached to a stereo microscope. The epigynes and the male pedipalps were removed for study. The epigynes were macerated in cold $5 \% \mathrm{KOH}$ for 24 hours, dehydrated with 100 ethanol, cleared in xylene and put in eugenol in temporary mounts. After examination, the genitalia were placed in micro-vials with ethanol and stored in the vials containing the specimens from which they had been removed. Terminology is standard for Araneae. The term 'spine' is used for a stout, rigid, pointed seta. Specimens were measured as in Metzner (1999), dimensions are given in millimetres. A Nikon Coolpix 8400 mounted on the stereo microscope was used to take digital photos, which were stacked using Helicon Focus image stacking software to increase the depth of field.

\section{Institutional abbreviations}

MNHN $=$ Muséum national d'Histoire naturelle, Paris, France

MRAC $=$ Museé Royal de l'Afrique Centrale, Tervuren, Belgium

$\mathrm{NHM}=$ Natural History Museum, London, UK

\section{Results}

\author{
Class Arachnida Cuvier, 1812 \\ Order Araneae Clerck, 1757 \\ Family Salticidae Blackwall, 1841 \\ Subfamily Salticinae Blackwall, 1841 \\ Clade Simonida Maddison, 2015 \\ Tribe Aelurillini Simon, 1901 \\ Subtribe Thiratoscirtina Bodner \& Maddison, 2012
}


Genus Pochytoides Berland \& Millot, 1941 stat. nov.

\section{Gender}

Feminine

\section{Type species}

Pochyta poissoni Berland \& Millot, 1941

\section{Diagnosis}

The genus is characterized by the structure of the genitalia. The male palps have a retrolateral tibial apophysis which is broad and straight, with a blunt tip and a dorsal apophysis which is long, thin and perpendicular to the palpal axis. The cymbium is narrow and the bulb is short, more or less triangular, with a well separated basal part and a large embolic division. The presence of a small, spike-like tegular apophysis on the prolateral side of the bulb is a distinctive feature. The epigynes have copulatory openings hidden in a deep and extremely sclerotized cup-shaped atria. The internal structure is simple with seminal ducts more or less short and straight and the spermathecae ovoid or spherical. The genitalic pattern is consistent throughout the whole genus.

\section{Description}

Small to medium spiders, ranging from about 3 to $5 \mathrm{~mm}$ in length. Carapace brown, oval, high and broad, with steep posterior slope beginning just behind the eye field. Eyes on small tubercles, with black rings around each (except as noted), eye field trapezoid, anterior row of eyes slightly wider than the posterior row. Anterior median eyes large. Fovea visible, sulciform, lying on small concave area. Clypeus vertical, low. Chelicerae large and long, fang relatively short, two teeth on promargin and a single large tooth on retromargin (Figs 9C, 11C). Endites slightly convergent. Labium trapezoid. Sternum shield-shaped. Pedicel short, not visible in dorsal view. Abdomen ovoid, slightly narrower than carapace. Legs more or less subequal, anterior pair slightly longer than others, especially in males. Spination of leg I in male: femur dorsally $0-1-1$ and $0-0-1$ prolaterally, patella 1 prolaterally, tibia ventrally $2-2-2-2$ and prolaterally $1-1-0$ or $1-0$, metatarsus ventrally $2-2$ and 2 apically on dorsal surface. Ventral spines on tibia and metatarsus extremely long (Fig. 9D). Spination of leg I in female similar, but spines on patella and prolateral surface of tibia absent. Female palp with single retrolateral spine on tarsus (Fig. 10A). Structure of genitalia: see Diagnosis.

\section{Remarks}

A large part of the bulb is enveloped by the cymbium, so that the study of this structure, and understanding its functional morphology, requires separation of the bulb from the cymbium. Unfortunately, insufficient numbers of male specimens prevented such study and the detailed bulb structure of only one species, P. spiniger sp. nov., is shown (Fig. 13E-G).

\section{Affinities}

The morphological characters mentioned in the introduction clearly show that Pochytoides is related to other genera included in the subtribe Thiratoscirtina Bodner \& Maddison, 2012 (sensu Maddison 2015) in the subfamily Salticinae Blackwall, 1841. At the moment, closer relationships of the genus remain unresolved and demand further molecular studies.

\section{A key to the species of Pochytoides}

\section{Males}

1. Pedipalp with short apophysis on the patella (Fig. 7C) ...................................... patellaris sp. nov.

- Pedipalp without patellar apophysis 2 
2. Embolic division serrated distally (Fig. 3A)

- Embolic division smooth distally

3. Embolus almost straight, with accompanying membrane (Fig. 9E)

- Embolus bent, without conspicuous membrane

P. poissoni (Berland \& Millot, 1941) comb. nov.

4. Anterior lobe of bulb expanding distally, axe-shaped (Fig. 11E)

P. securis sp. nov.

- Anterior lobe of bulb tapering distally

5. Embolic division curved toward prolateral side of the palp (Fig. 5A)

P. obstipa sp. nov.

- Embolic division sigmoid, its tip curved toward retrolateral side

6. Prolateral edge of anterior lobe of bulb with spine at base (Fig. 13C)

P. spiniger sp. nov.

- Prolateral edge of anterior lobe of bulb strongly sclerotized, but without spine (Fig. 1B)

P. lamottei sp. nov.

\section{Females}

1. Epigyne without pockets

- Epigyne with paired pockets at epigastric furrow

2. Area occupied by atria broader than spermathecae area (Fig. 8D)

..P. perezi (Berland \& Millot, 1941) comb. nov.

- Area occupied by atria narrower than spermathecae area (Fig. 15C) P. spiniger sp. nov.

3. Atria weakly sclerotized (Fig. 12C) P. securis sp. nov.

- Atria strongly sclerotized

4. Area occupied by atria narrower than spermathecae area (Fig. 2C)

P. lamottei sp. nov.

- Area occupied by atria broader than spermathecae area 5

5. Two semicircular hoods in front of atria, spermathecae spherical (Fig. 10D)

P. poissoni (Berland \& Millot, 1941) comb. nov.

- Shallow depression in front of atria, spermathecae oval.

6. Posterior edge of epigynal depression straight, pockets placed posteriorly to spermathecae (Fig. 4B)

P. monticola sp. nov.

- Posterior edge of epigynal depression arched, pockets placed at spermathecae level (Fig. 6C)

..P. obstipa sp. nov.

\section{Pochytoides lamottei sp. nov. \\ urn:1sid:zoobank.org:act:64040FFC-964C-424B-AB7B-55B1B64A7AD4}

Figs 1-2

\section{Etymology}

The species is dedicated to Prof. M. Lamotte, an ecologist who collected many spiders in the Nimba Mts.

\section{Type material}

\section{Holotype}

GUINEA: ${ }^{\lambda}$, Mts Nimba, Praira, $7^{\circ} 34^{\prime}$ N, $8^{\circ} 28^{\prime}$ W, 1600 m a.s.l., savanna with Andropogon, 20 Jun. 1942, M. Lamotte leg. (NHM). 


\section{Paratypes}

GUINEA: 1 ㅇ, together with holotype (NHM); 1 ㅇ, Mts Nimba, savanna, 1952-1962, M. Lamotte leg. (NHM); 1 क, Mts Nimba, Seringbara forest, 606 m a.s.l., pitfall, 19 Mar. 2012, A. Hernard et al. leg. (MRAC 239 473B); 1 ㅇ, same locality, in litter, sieving, 13 Mar. 2012, A. Hernard et al. leg. (MRAC 239 034A); 1 ㅇ, same locality, in litter, sieving, 18 Feb. 2012, A. Hernard et al. leg. (MRAC 239 176A); 4 우, Mts Nimba, station de pompage Zié, $1250 \mathrm{~m}$ a.s.l., forest, litter under high grass, sieving, 11 Oct. 2011, Van den Spiegel and A. Hernard leg. (MRAC 237 944); 1 ð̂, same locality, 1 Oct. 2011 (MRAC 238 094); 1 ठ, same locality, gallery forest, on vegetation, hand collecting,
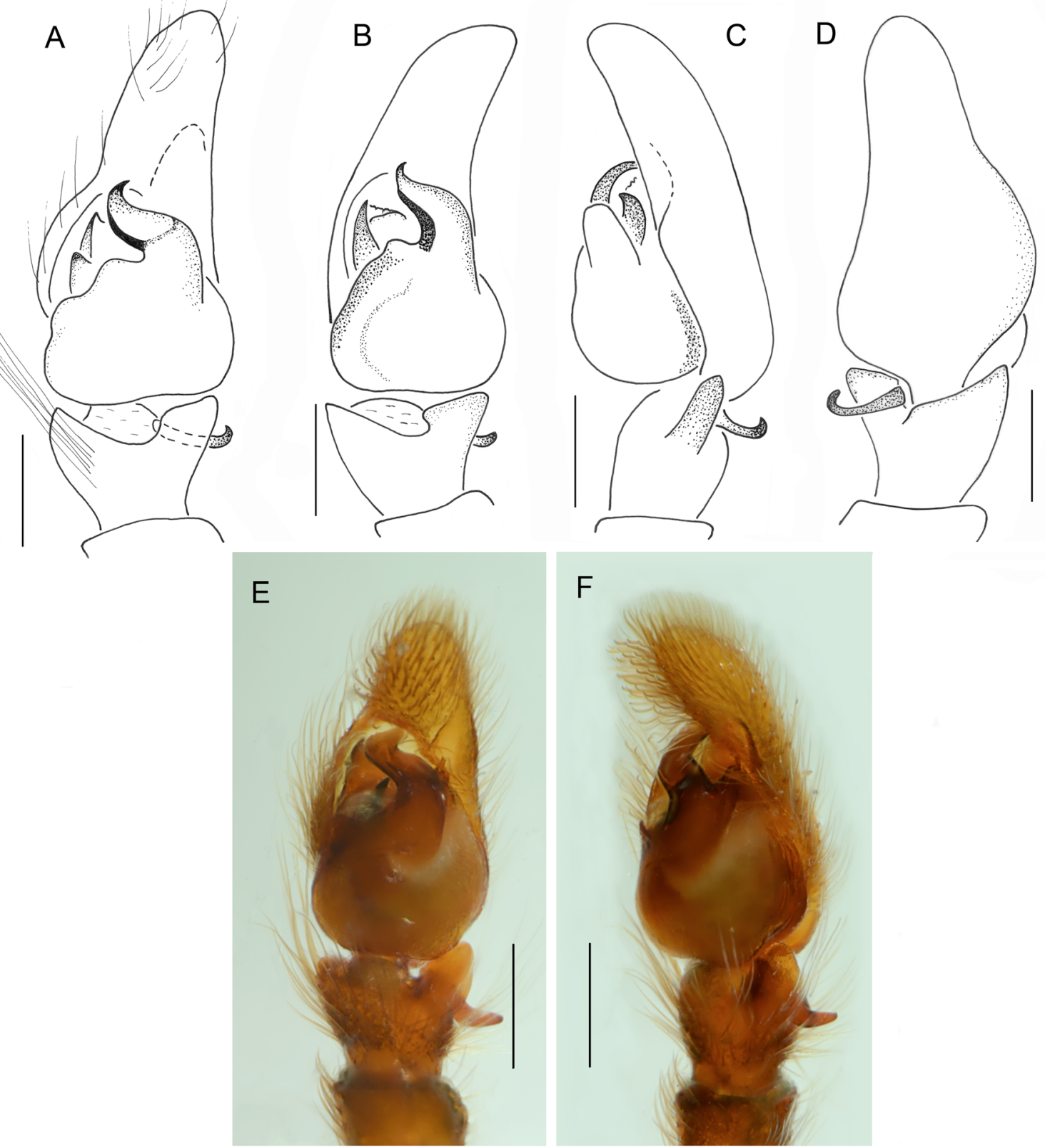

Fig. 1. Pochytoides lamottei sp. nov., $\widehat{O}$, holotype (A-D) and paratypes (E-F). A-E. Palpal organ. A, E. Ventral view. B. Ventroprolateral view. C. Retrolateral view. D. Dorsal view. F. Ventroretrolateral view. Scale bars: $0.3 \mathrm{~mm}$. 
1 Oct. 2011 (MRAC 237 901); 1 ðे, Mts Nimba, Gba valley, $880 \mathrm{~m}$ a.s.1., primary forest, hand collecting, 9 Oct. 2012, Van den Spiegel and A. Hernard leg. (MRAC 238 015A); 1 ðૈ, Mts Nimba, Newené, $545 \mathrm{~m}$ a.s.l., near river, dry litter, sieving, 25 Feb. 2012, A. Hernard et al. leg. (MRAC 238 900A).

\section{Differential diagnosis}

The male palp is similar to that of $P$. spiniger sp. nov. in having a sinusoid anterior lobe of the bulb, but may be recognized by the strongly sclerotized keel on the prolateral edge of this lobe and the absence of a spine at the base (compare Fig. 1A-C with Fig. 13A-C). The female slightly resembles those of $P$. securis sp. nov. and $P$. spiniger sp. nov. They share an epigyne in which the distance between the lateral edges of the atria is smaller than the distance between the lateral edges of the spermathecae. However, $P$. lamottei sp. nov. may be distinguished by the atria, which are cup-shaped (narrower in the other species,

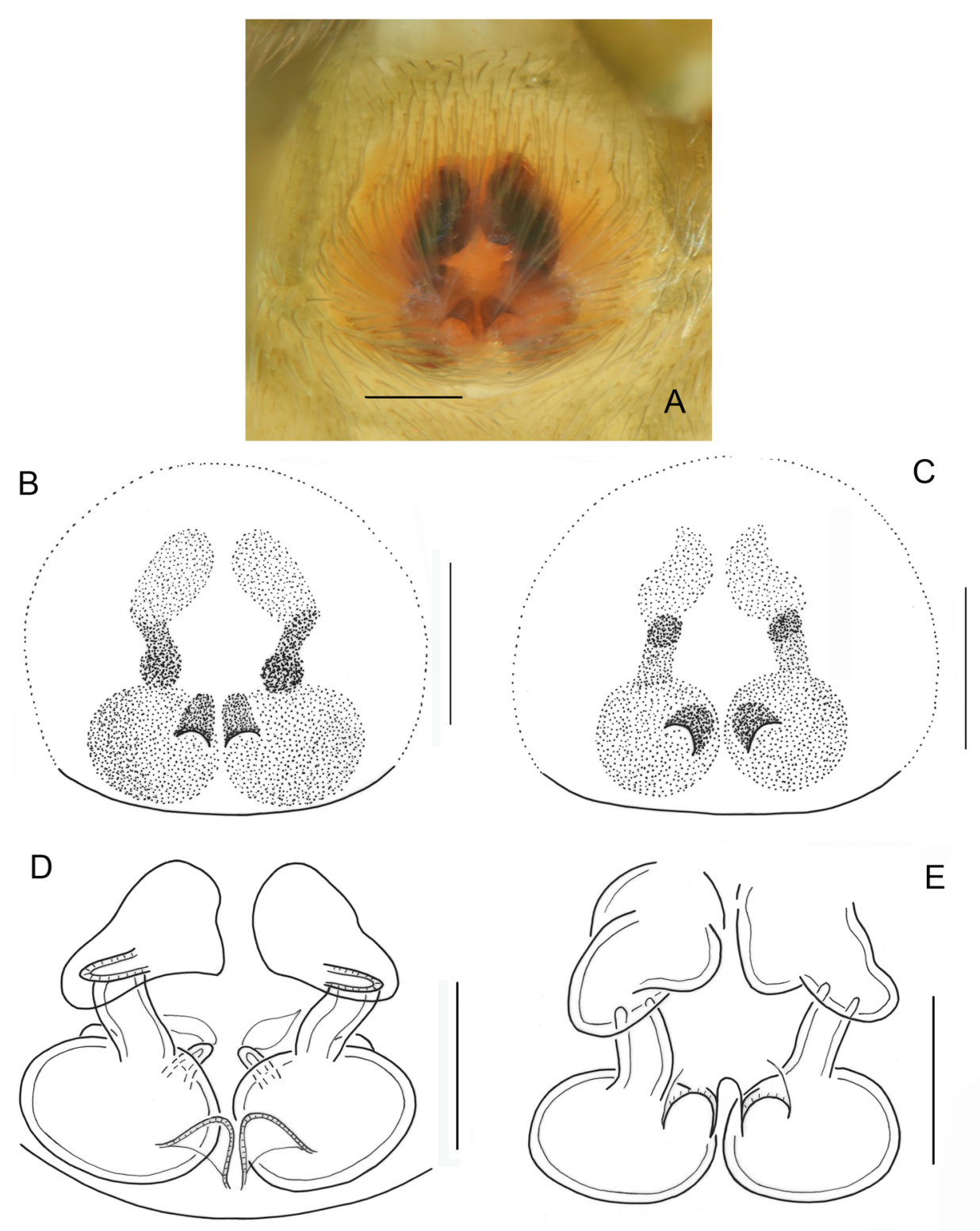

Fig. 2. Pochytoides lamottei sp. nov., paratypes, + . A-C. Epigyne. D-E. Internal structure of epigyne. Scale bars: $0.2 \mathrm{~mm}$. 
compare Fig. 2A-C with Figs. 12A-B and 15A-C). Pochytoides lamottei sp. nov. also differs from $P$. spiniger sp. nov. by the presence of epigynal pockets and from $P$. securis sp. nov. by clearly shorter seminal ducts.

\section{Description}

Male

Dimensions. Cephalothorax: length 2.1-2.2, width 1.7-1.9, height 1.4-1.5. Eye field: length 1.0-1.1, anterior width 1.6-1.8, posterior width 1.7-1.4. Abdomen: length 1.8-2.0, width 1.3-1.5.

Colour AND BODY. Carapace and eyes as in genus description. Greyish brown with pale chevrons on posterior half. Legs yellow, ventral spines on tibia and metatarsus I very long.

Genitalia. Palpal organ as in Fig. 1A-F. Cymbium very long, with prolateral edge slightly wrapped toward the ventral side of the palp. Bulb short, prolateral border of its anterior lobe heavy sclerotized, but not forming separate spine (Fig. 1A-B).

\section{Female}

DimENsions. Cephalothorax: length 1.9-2.0, width 1.6-1.7, height 0.9-1.0. Eye field: length 1.1-1.2, anterior width 1.5-1.6, posterior width 1.3-1.4. Abdomen: length 2.1-2.4, width 1.5-1.7.

Colour AND BODY. Faint colourless hairs on carapace, anterior eyes encircled by small grey scales. Abdomen oval, dark, brownish grey with light chevrons posteriorly. Venter yellowish, sides with grey marks. Spinnerets pale. Legs brown, femora darker, tarsi slightly lighter. Pedipalps yellowish.

Genitalia. Epigyne rounded, with pair of pockets (Fig. 2A-C). Internal structure as in Fig. 2D-E, copulatory openings hidden in large atria, seminal ducts short.

Pochytoides monticola sp. nov. urn:1sid:zoobank.org:act:22EDF7B4-5660-41B0-BB80-794BDB27AF08

Figs 3-4

\section{Etymology}

The specific name is Latin, meaning a dweller among the mountains, it refers to the occurrence of the species in montane habitats.

\section{Type material}

\section{Holotype}

GUINEA: $\widehat{\partial}^{\top}$, Mts Nimba, Nion, $7^{\circ} 36^{\prime}$ N, $8^{\circ} 28^{\prime}$ W, 16 Jun. 1942, M. Lamotte leg. (NHM).

\section{Paratypes}

GUINEA: 1 \%, together with holotype (NHM); 1 q, Mts Nimba, $7^{\circ} 34^{\prime} \mathrm{N}, 8^{\circ} 28^{\prime} \mathrm{W}$, grassy area, $1952-$ 1962, M. Lamotte leg. (NHM).

\section{Differential diagnosis}

The male differs from the other males of Pochytoides in having a uniquely shaped of the embolic division that is serrated at the tip (Fig. 3A). The female may be distinguished by the form of the epigyne, similar to that of $P$. perezi comb. nov. and P. obstipa sp. nov., all of which have a wide field occupied by atria. However, P. monticola sp. nov. can be distinguished from P. perezi comb. nov. by the shape of the epigynal depression, which is a narrow horizontal gap (V-shaped in P. perezi comb. nov., compare 
Fig. 4A-B, with Fig. 8B-C). Pochytoides monticola sp. nov. differs from P. obstipa sp. nov. by the position of the pockets (posterior to the spermathecae, Fig. 4A-B), whereas $P$. obstipa sp. nov. has pockets placed closer to the centre of the spermathecae (Fig. 6A-D).

\section{Description}

Male

DimENSions. Cephalothorax: length 2.4, width 2.0, height 1.5. Eye field: length 1.5, anterior width 1.9, posterior width 1.7. Abdomen: length 2.0, width 1.5.

COLOUR AND BODY. Carapace and eyes as in genus description. Abdomen ovoid, beige greyish with white chevrons in posterior half. Body clothed in fine hairs, some longer bristles only at first row of eyes and on anterior edge of abdomen. Legs dark yellow, bearing light hairs.

Genitalia. Palpal organ with short bulb, embolic division with characteristic tip, terminated by three teeth (Fig. 3A-D).

\section{Female}

DimEnsions. Cephalothorax: length 1.8, width 1.7, height 1.2. Eye field: length 1.2, anterior width 1.6, posterior width 1.4. Abdomen: 2.2, width 1.8.

Colour AND BODY. Morphologically similar to other species. Carapace dark, covered with fine brown hairs, light greyish white hairs only on slopes. Abdomen bleached, with traces of large butterfly-shaped pale patch on dorsum.

A

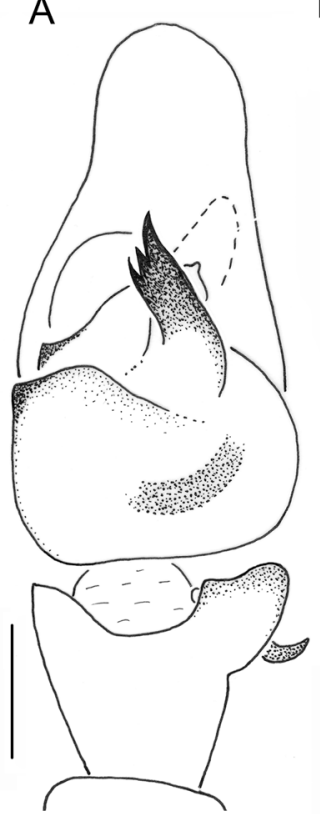

B

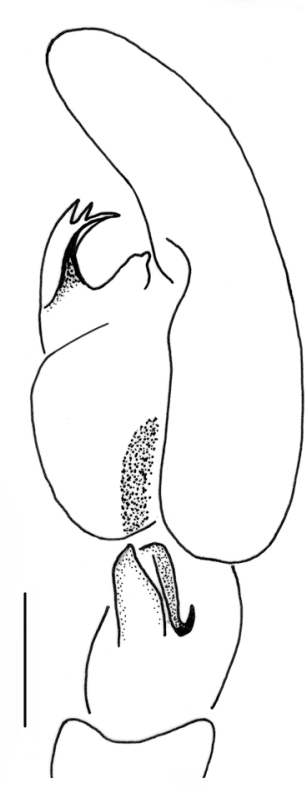

C

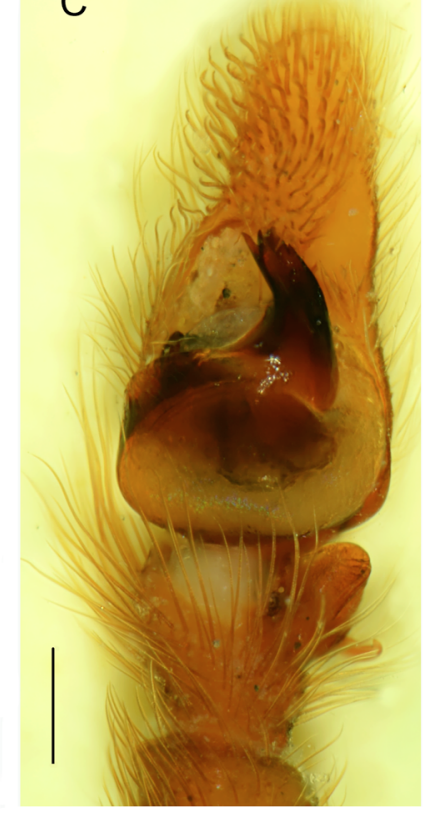

D

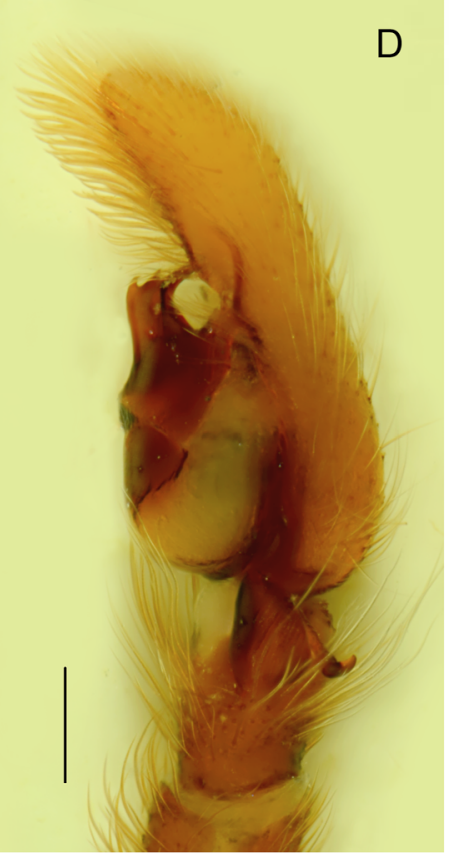

Fig. 3. Pochytoides monticola sp. nov., holotype, ô. A-D. Palpal organ. A, C. Ventral view. B, D. Retrolateral view. Scale bars: $0.3 \mathrm{~mm}$. 

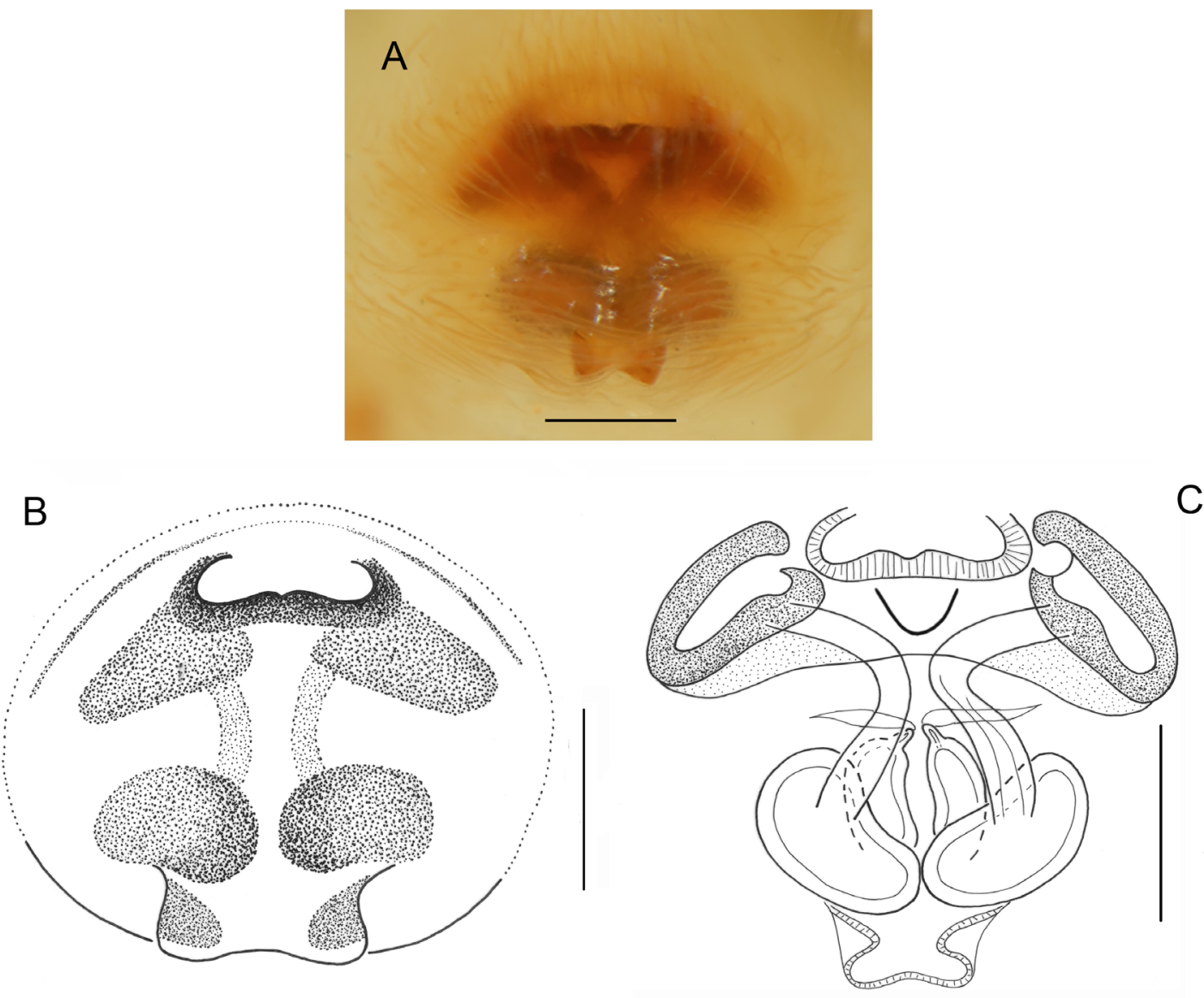

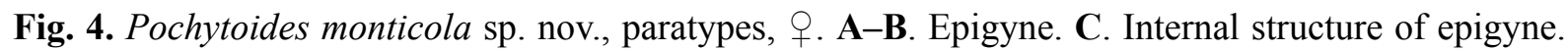
Scale bars: $0.2 \mathrm{~mm}$.

Genitalia. Epigyne with wide but low depression anteriorly and posterior plate with two separated pockets (Fig. 4A-B). Atria deep, strongly sclerotized, copulatory canals relatively long (Fig. 4C).

\section{Remarks}

Matching of sexes uncertain.

\section{Pochytoides obstipa sp. nov.}

urn:lsid:zoobank.org:act:173C9B4F-1596-4BEB-BE51-FE45B344E820

Figs 5-6

\section{Etymology}

The specific epithet is Latin for shrunken and refers to the short bulb.

\section{Type material}

\section{Holotype}

GUINEA: §ึ, Mts Nimba, Seringbara, Isro forest, $593 \mathrm{~m}$ a.s.1., secondary forest, soil litter, 24 Feb. 2012, A. Hernard, C. Allard, P. Bimou and M. Sidibé leg. (MRAC 239 091). 


\section{Paratypes}

GUINEA: 1 +, same locality as holotype, 24 Feb. 2012, A. Hernard et al. leg. (MRAC 239 249); 1 ठૈ, 1 ․ Mts Nimba, Oct.1951, M. Lamotte leg. (NHM); 2 우, Mts Nimba, Praira, $7^{\circ} 34^{\prime} \mathrm{N}, 8^{\circ} 28^{\prime} \mathrm{W}$, 1600 m a.s.1., savanna with Andropogon, 20 Jun. 1942, M. Lamotte leg. (NHM); 1 +, Mts Nimba, bank

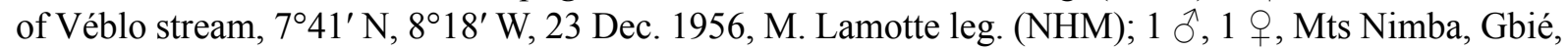
469 m a.s.l., near river, in litter, sieving, 15 Mar. 2012, A. Hernard et al. leg. (MRAC 238 738B); 1 , Mts Nimba, station de pompage Zié, $1250 \mathrm{~m}$ a.s.l., forest, litter under high grass, sieving, 11 Oct. 2011, Van den Spiegel and A. Hernard leg. (MRAC 237 989); 1 q, Mts Nimba, Freton, 572 m a.s.l., soil litter, sieving, 10 Mar. 2012, A. Hernard et al. leg. (MRAC 238 689).
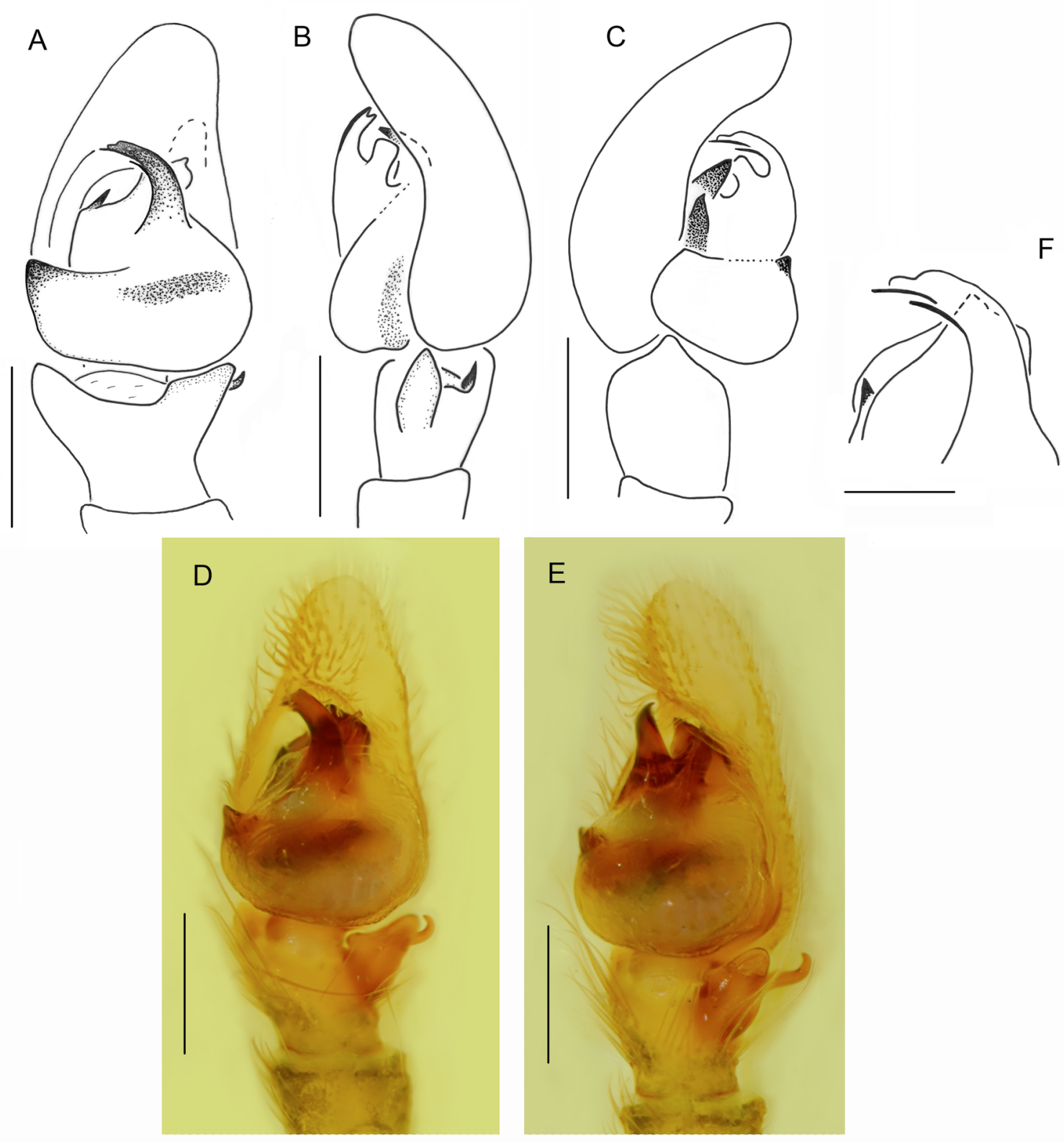

Fig. 5. Pochytoides obstipa sp. nov., paratypes, ô. A-E. Palpal organ, A, D. Ventral view. B. Retrolateral view. C. Ventroprolateral view. E. Ventroretrolateral view F. Embolic division. Scale bars: A-E = $0.3 \mathrm{~mm}, \mathrm{~F}=0.1 \mathrm{~mm}$. 


\section{Differential diagnosis}

The male of $P$. obstipa sp. nov. is similar to that of $P$. monticola sp. nov., but can be distinguished by the shape of the embolic division, which is ribbon-like in the former species (Fig.5A) and serrated in the latter (Fig. 3A). The female is similar to that of P. poissoni comb. nov., sharing the epigyne with paired pockets placed at the level of the spermathecae, but can be distinguished from it by the shape of the shallow anterior depression which does not have a clearly marked anterior edge (Fig. 6A-D) as opposed to a distinct two-arched edge in P. poissoni comb. nov. (Fig. 10A-F).
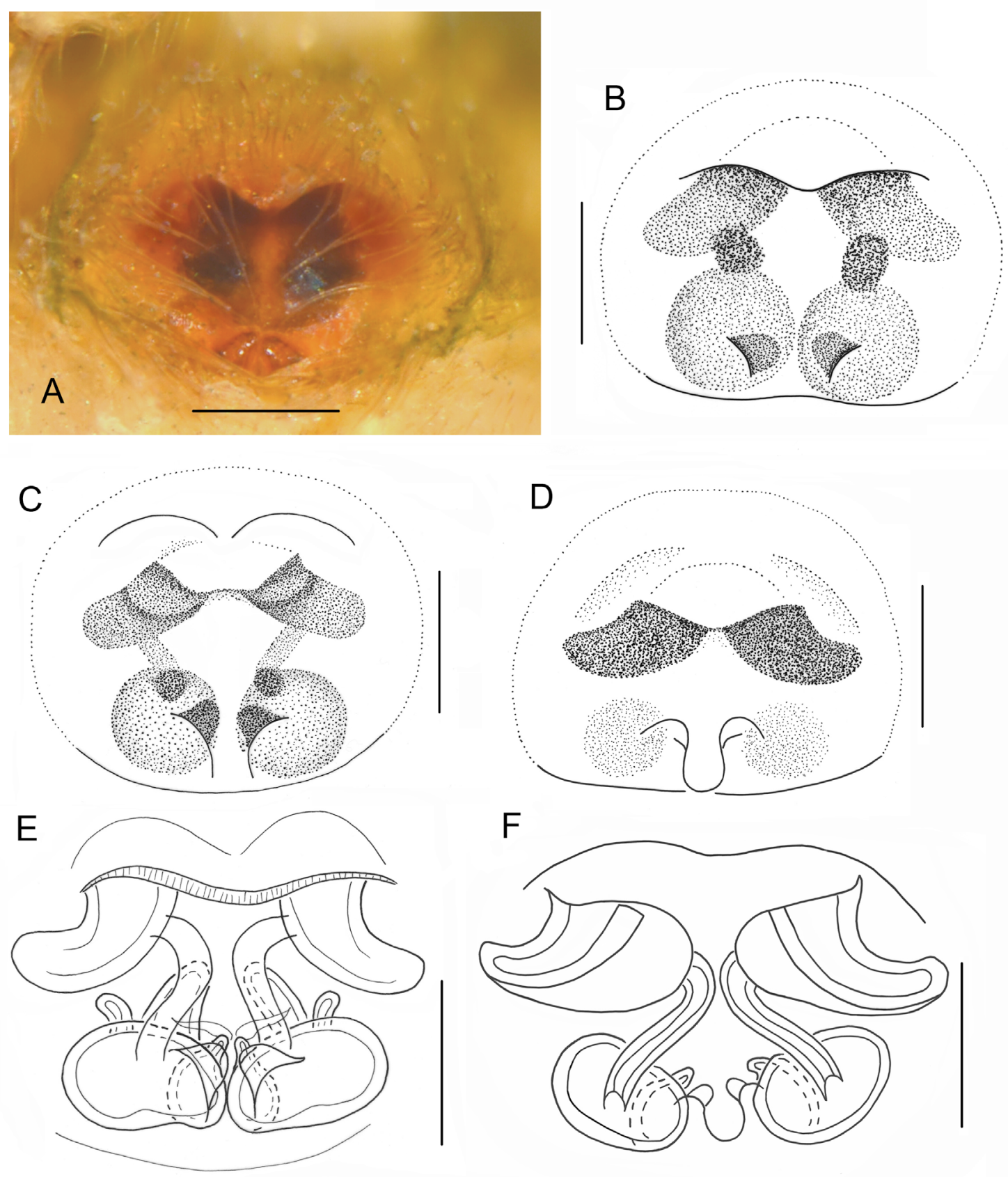

Fig. 6. Pochytoides obstipa sp. nov., paratypes, +. A-D. Epigyne. E-F. Internal structure of epigyne. Scale bars: $0.2 \mathrm{~mm}$. 


\section{Description}

Male

Dimensions. Cephalothorax: length 1.6-1.7, width 1.3-1.5, height 0.9-1.0. Eye field: length 0.8-0.9, anterior width 1.3-1.4, posterior width 1.1-1.2. Abdomen: length 1.3-1.4, width 1.0-1.2.

Colour AND BODY. Very small spider. Carapace light brown, eyes encircled by dark rings, some dark scales above anterior median eyes. Abdomen ovoid, bleached, beige greyish with traces of white chevrons. Body clothed in delicate colourless hairs, some white hairs on slopes of carapace. Legs dark yellow, bases and tips of their segments slightly darker, femora of first pair of legs brown.

Genitalia. Palpal organ as in Fig. 5A-E, with short bulb, posterior lobe of the bulb wide, forming protruding prolateral rim. Embolic division curved toward prolateral side, ribbon like (Fig. 5F).

\section{Female}

DimEnsions. Cephalothorax: length 1.7-2.0, width 1.5-1.8, height 1.0-1.1. Eye field: length 0.9-1.1, anterior width 1.3-1.5, posterior width 1.1-1.4. Abdomen: length 1.6-2.3, width 1.3-1.7.

Colour AND BODy. Similar to male. A few whitish scales between anterior median eyes and anterior laterals, long light bristles beside anterior eyes. Some white hairs on slopes of carapace. Sternum yellow, mouthparts light brown. Abdomen greyish with median pale serrate band, lateral sides mottled. Spinnerets grey. First pair of legs light brown, others yellowish with brown sides of femora and darker rings on bases and tips of segments. Spines brown, leg hairs light. Pedipalp brown, its tarsus yellow.

GenITALIA. Epigyne with two pockets, usually clearly visible, and small groove anteriorly (Fig. 6A-D; each of the following figures show individual variation). Copulatory openings hidden in very deep atria, accessory glands connected to spermathecae (Fig. 6E-F).

Pochytoides patellaris sp. nov. urn:lsid:zoobank.org:act:B17A55DA-5BD4-4C44-91FB-C125676BB6DA

Fig. 7

\section{Etymology}

The specific name refers to the presence of an apophysis on the palpal patella.

\section{Type material}

\section{Holotype}

GUINEA: ${ }^{\curvearrowright}$, Mts Nimba, grassy area, 1952-1962, M. Lamotte leg. (NHM).

\section{Paratype}

GUINEA: $1 \hat{\jmath}$, together with holotype (NHM).

\section{Differential diagnosis}

The male is similar to that of P. poissoni comb. nov. in having an embolus with accompanying membrane, but may be distinguished by the presence of a small patellar apophysis (Fig. 7A, C, F-G).

\section{Description}

Male

Dimensions. Cephalothorax: length 2.3-2.4, width 1.9-2.1, height 1.3-1.5. Eye field: length 1.2-1.4, anterior width 1.8-1.9, posterior width 1.6-1.8. Abdomen: length 1.9-2.2, width 1.4-1.5. 


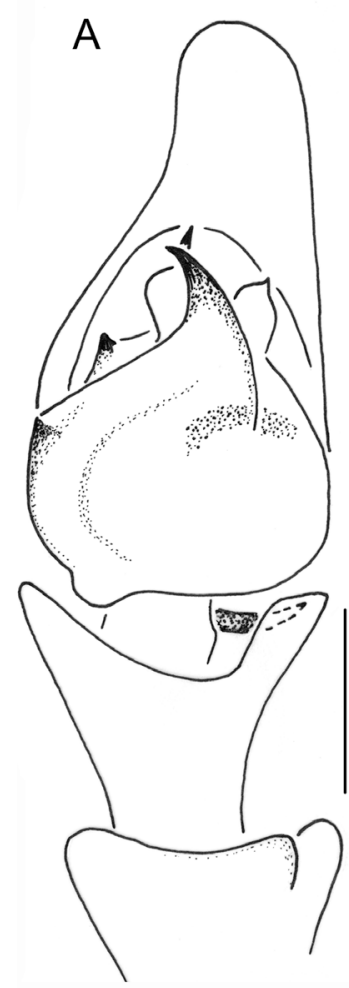

G

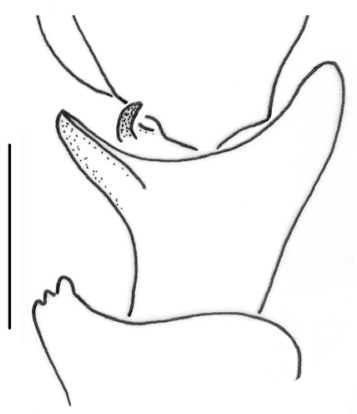

B
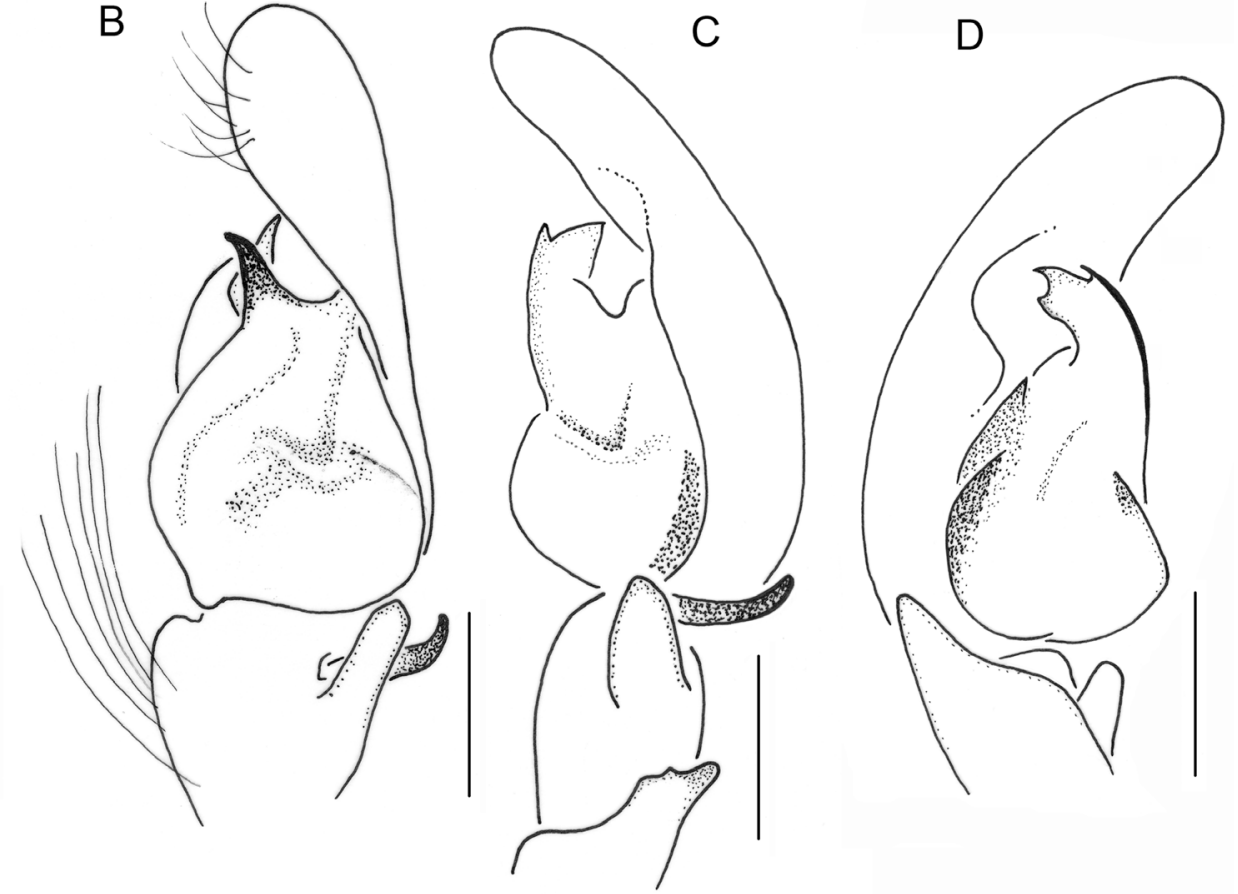

E

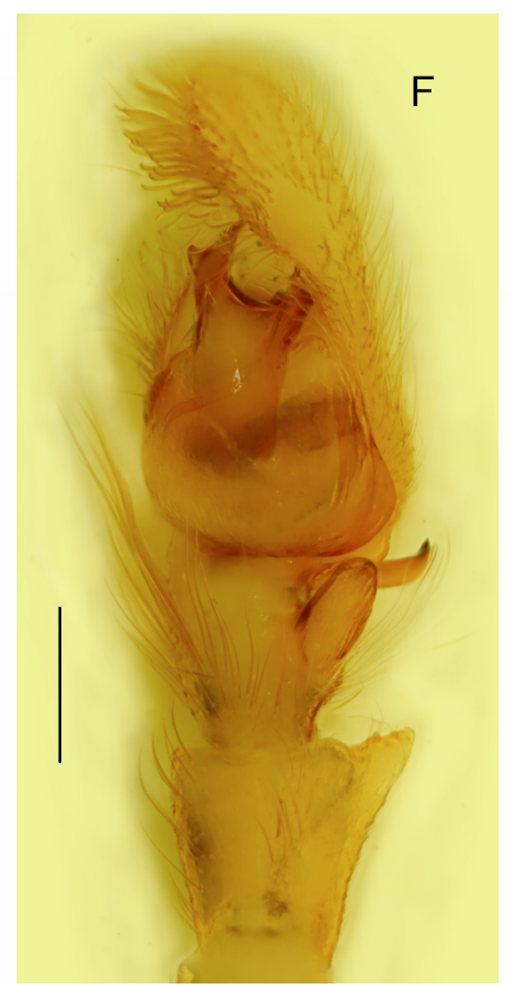

Fig. 7. Pochytoides patellaris sp. nov., holotype, Ô. A-F. Palpal organ. A, E. Ventral view. B, F. Ventroretrolateral view. C. Retrolateral view. D. Ventroprolateral view. G. Palpal apophyses, dorsal view. Scale bars: $0.3 \mathrm{~mm}$. 
COLOUR AND BODY. Carapace brownish with slopes slightly darker but covered by light hairs. Anterior eyes encircled by fawn scales. Abdomen greyish with large light patch in anterior half and chevrons posteriorly, clothed in fine hairs, among them some longer bristles. Legs yellow with darker rings.

Genitalia. Pedipalps pale, yellowish. Palpal organ as in Fig. 7A-G. Short but clear retrolateral apophysis on palpal patella (Fig. 7A, C, F-G). Embolus slightly curved to prolateral side, with accompanying membrane (Fig. 7A).

\section{Female}

Unknown.

Pochytoides perezi (Berland \& Millot, 1941) comb. nov.

Fig. 8

Pochyta (Pochytoides) perezi Berland \& Millot, 1941: 362, fig. 63a-c.

\section{Type material}

\section{Holotype}

GUINEA: + , Macenta, $08^{\circ} 33^{\prime}$ N, 09²8' W [620 m a.s.1.], [1937, leg. J. Millot] (MNHN).
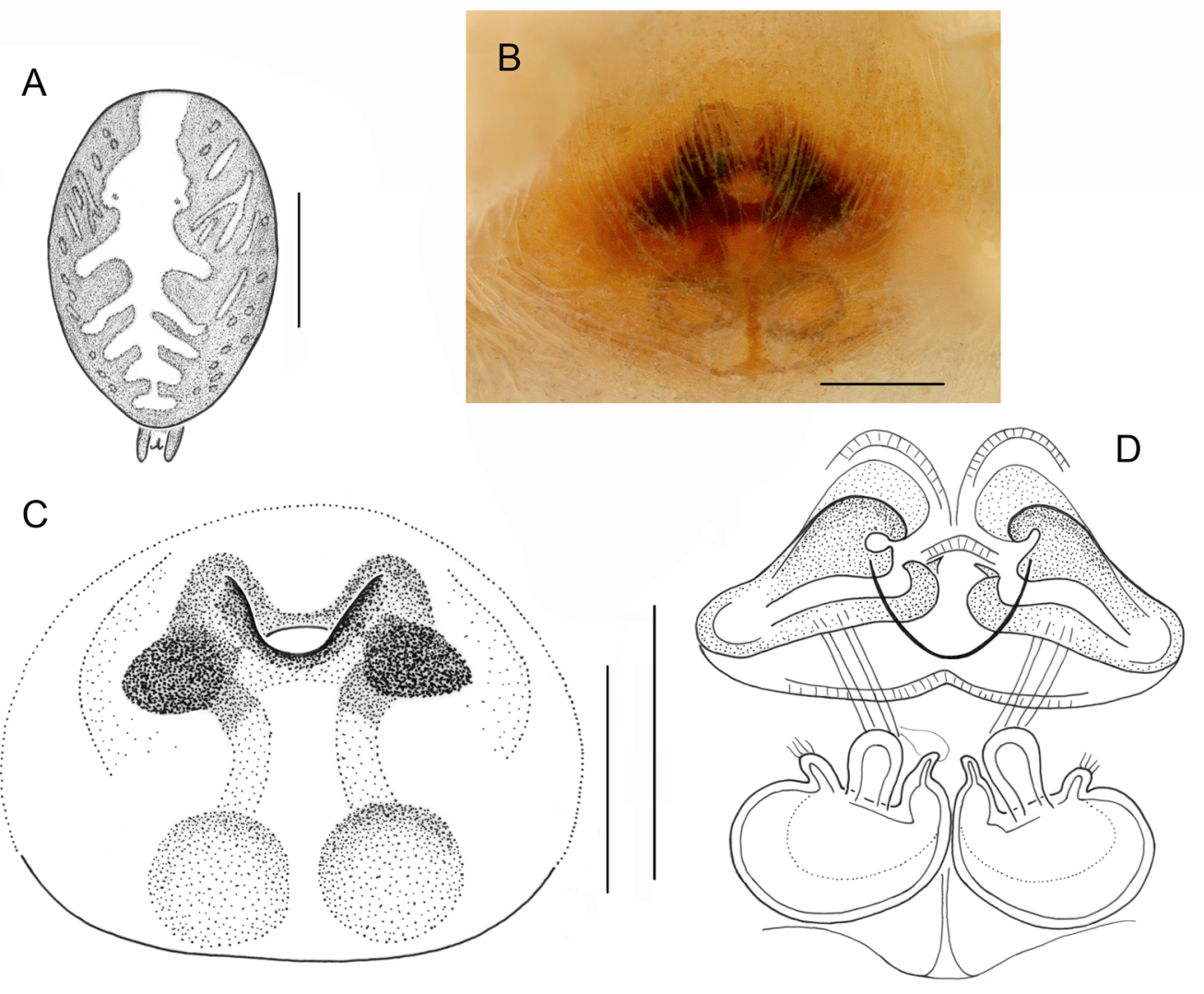

Fig. 8. Pochytoides perezi (Berland \& Millot, 1941) comb. nov., holotype, +. A. Abdominal pattern. B-C. Epigyne. D. Internal structure of epigyne. Scale bars: A $=1.0 \mathrm{~mm}, \mathrm{~B}-\mathrm{D}=0.2 \mathrm{~mm}$. 


\section{Differential diagnosis}

The female has an epigyne similar to that of $P$. spiniger sp. nov., sharing the V-shaped anterior epigynal depression and the absence of pockets, but may be distinguished by having a broader area occupied by the atria than that of $P$. spiniger sp. nov. in comparison to the area surrounding the spermathecae (compare Fig. 8B-C with Fig. 15A-C).

\section{Redescription}

\section{Male}

Unknown.

\section{Female}

DimENsions. Cephalothorax: length 2.1, width 1.7, height 1.2. Abdomen: length 2.0, width 1.6. Eye field: length 1.1, anterior width 1.5 , posterior width 1.4 .

COLOUR AND BODY. Carapace dark brown, covered with fine hairs. Eye field darker, some brown bristles at anterior eyes. Abdomen brown with lighter herring-bone pattern dorsally and numerous patches on lateral sides (Fig. 8A). Spinnerets brownish. Legs long, yellow, with delicate yellowish hairs.

GenITALiA. Epigyne strongly sclerotized, especially anteriorly where characteristic plate with small depression between atria is situated (Fig. 8B-C). Copulatory openings hidden in very deep atria, accessory glands connected to spermathecae (Fig. 8D).

Pochytoides poissoni (Berland \& Millot, 1941) comb. nov.

Figs 9-10

Pochyta (Pochytoides) poissoni Berland \& Millot, 1941: 363, fig. 64a-b.

\section{Type material}

\section{Holotype}

GUINEA: , , Macenta, $08^{\circ} 33^{\prime}$ N, 09²8' W [620 m a.s.1.], [1937, leg. J. Millot] (MNHN).

\section{Other material}

GUINEA: $1 \hat{\partial}$, together with holotype (MNHN); 1 + , Mts Nimba, Praira, 1600 m a.s.1., 7³4' N, $8^{\circ} 28^{\prime}$ W, savanna with Andropogon, 20 Jun. 1942, M. Lamotte leg. (NHM); 1 \%, Mts Nimba, Ziéla, 500 m a.s.1., 16-20 Dec. 1956, M. Lamotte leg. (NHM); 1 ㅇ, Mts Nimba, Fouenyi forest, 573 m a.s.l., soil litter, sieving, 1 Mar. 2012, A. Hernard et al. leg. (MRAC 238 838B).

\section{Differential diagnosis}

The male is similar to that of $P$. patellaris sp. nov. in having an embolus with accompanying membrane, but may be distinguished by the orientation of the embolar tip (retrolateral in P. poissoni comb. nov., prolateral in P. patellaris sp. nov.) and by the absence of a patellar apophysis. The female is slightly similar to that of $P$. obstipa sp. nov.; both species have an epigyne with paired pockets placed near the epigastric furrow at the level of the spermathecae, but P. poissoni comb. nov. can be separated by the clearly smaller atria and characteristic wavy edge of the atrial area (compare Fig. 10A-F with Fig. 6A-D).

\section{Redescription}

Male

DimENsions. Cephalothorax: length 2.3, width 1.4, height 1.1. Abdomen: length1.5, width 1.0. Eye field: length 0.9 , anterior width 1.4 , posterior width 1.3 . 


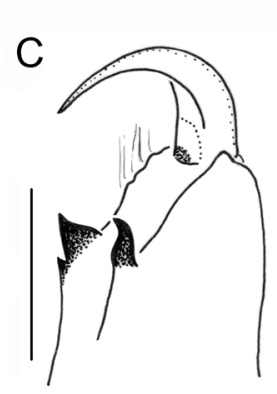

$\mathrm{D}$

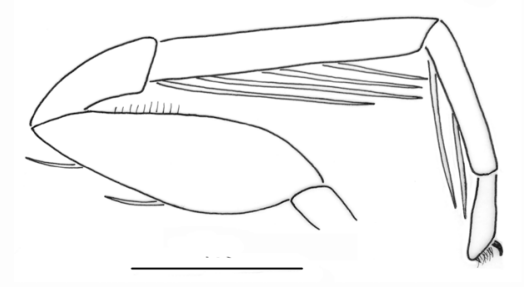

A
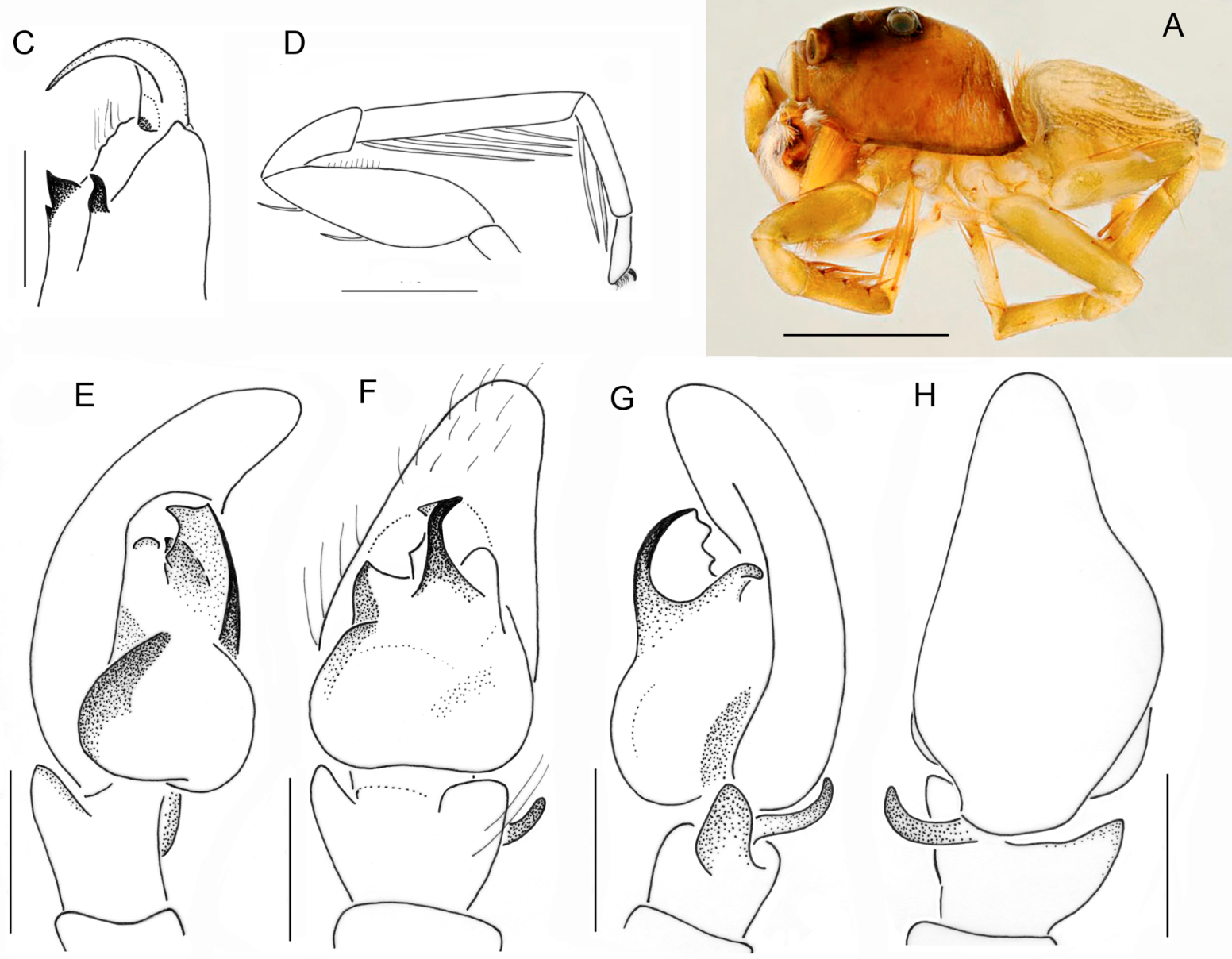

G
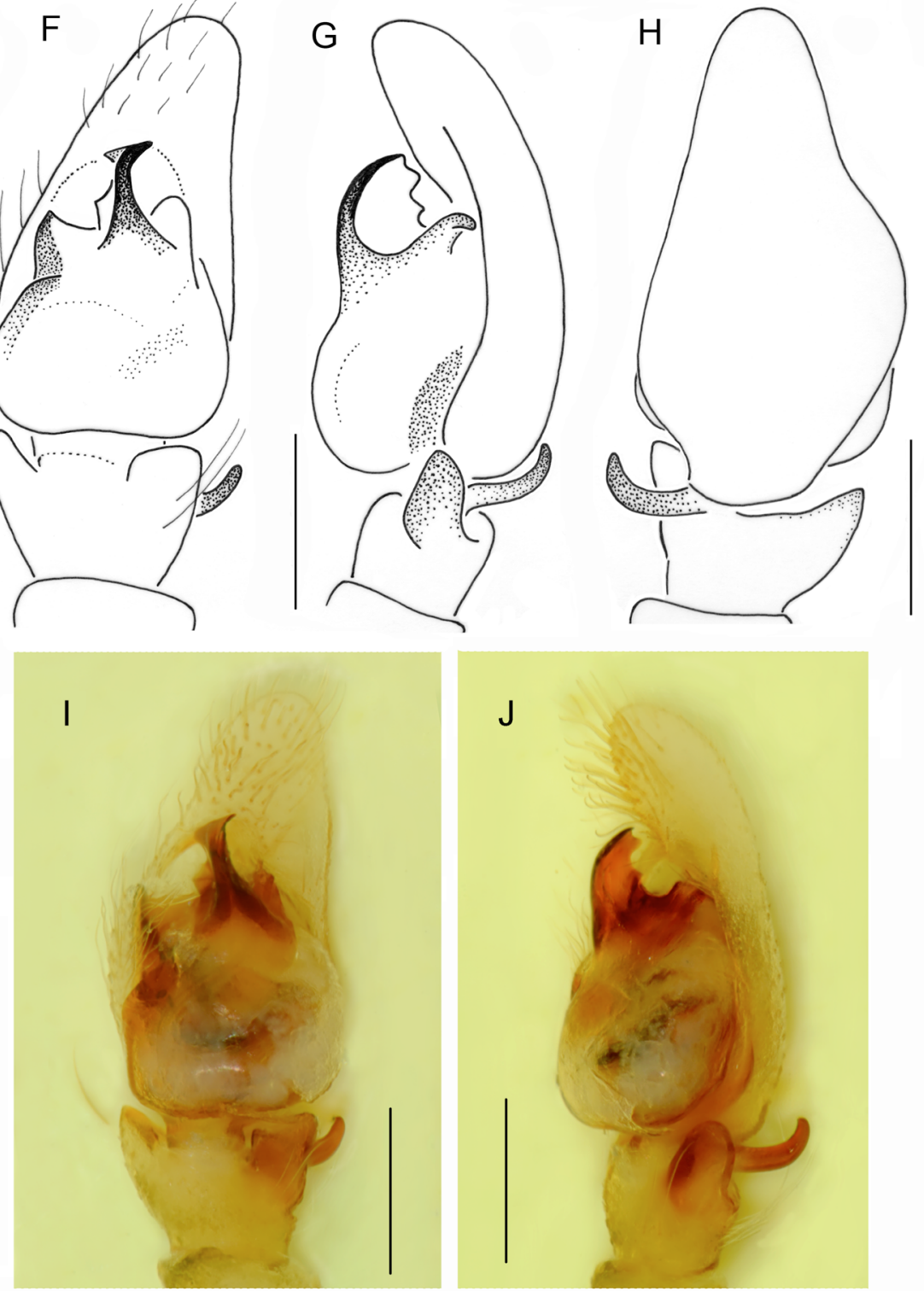

B

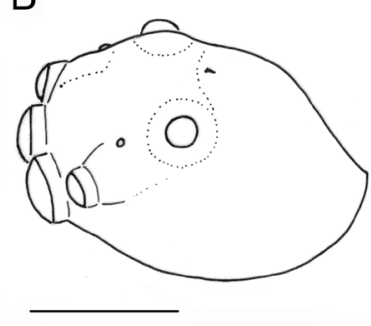

Fig. 9. Pochytoides poissoni (Berland \& Millot, 1941) comb. nov., ठ̂. A. General appearance, lateral view. B. Carapace, dorsolateral view. C. Cheliceral dentition. D. First leg. E-K. Palpal organ. E. Ventroprolateral view. F, I. Ventral view. G, J. Retrolateral view. H. Dorsal view. Scale bars: A-B, $\mathrm{D}=1.0 \mathrm{~mm}, \mathrm{C}, \mathrm{E}-\mathrm{K}=0.3 \mathrm{~mm}$. 
Colour AND BODy. General appearance as in Fig. 9A. Carapace abruptly sloping posteriorly (Fig. 9B), covered with delicate colourless hairs, some white hairs on slopes. Anterior medians lack black rings, long bristles near eyes. Fovea visible. Clypeus low, with white hairs. Chelicerae dark yellow, fang short, dentition as in Fig. 9C. Labium, endites and sternum dark yellowish. Abdomen smaller than cephalothorax, oval, yellowish grey (probably bleached) with traces of lighter chevrons in posterior half, some brown bristles on abdominal dorsum, denser at anterior edge. Spinnerets yellow. Legs long, light brown. Ventral spines of tibia and metatarsus extremely long (Fig. 9D). Short, stiff and sharp hairs on ventral surface of first femur.

Genitalia. Pedipalps yellow with white hairs on cymbium, tibia short with short broad retrolateral and prolateral apophyses (Fig. 9F, J) and thin horizontal apophysis on dorsum (Fig. 9H). Embolus nearly straight, only the tip curved to retrolateral side, with large accompanying membrane (Fig. 9E-G, J-K).

\section{Female}

DimENSiOns. Cephalothorax: length 2.0-2.2, width 1.5-1.8, height 1.0-1.1. Abdomen: length 2.0-2.6, width 1.4-1.9. Eye field: length 1.0-1.2, anterior width 1.5-1.8, posterior width 1.4-1.7.
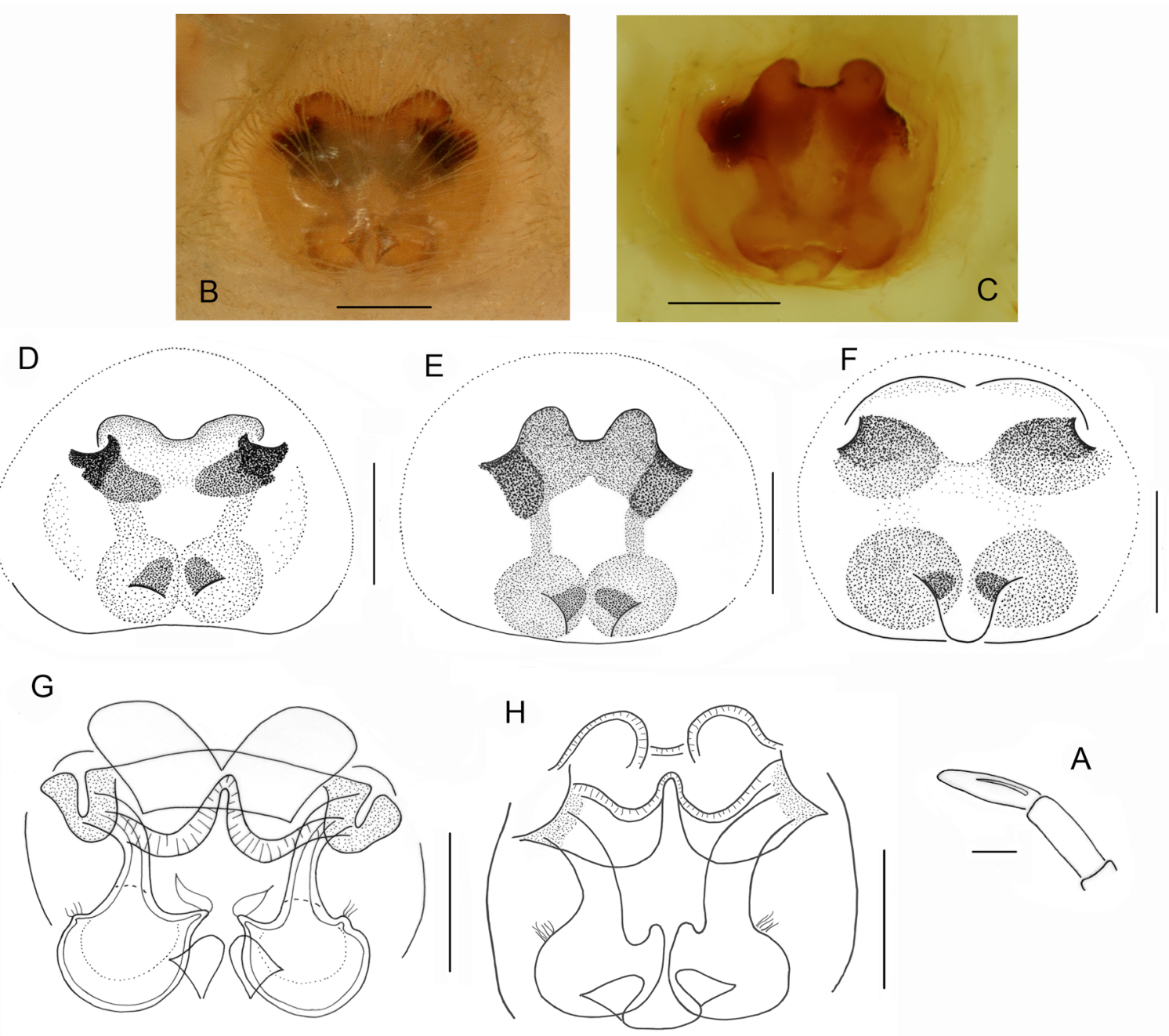

Fig. 10. Pochytoides poissoni (Berland \& Millot, 1941) comb. nov., holotype, $q$ (B, D, G), specimen from Ziéla (A, C, E, H) and specimen from Fouenyi (F). A. Tip of female's palp. B-F. Epigyne. G-H. Internal structure of epigyne. Scale bars: $A=0.3 \mathrm{~mm}, \mathrm{~B}-\mathrm{H}=0.2 \mathrm{~mm}$. 
ColOUR AND BODY. Shape of body as in male, only leg I shorter. Some white hairs on slopes of carapace. Chelicerae as in male, only retromarginal tooth slightly smaller. Abdominal pattern with more contrast than in male, two parallel light bands on greyish background in anterior part and a few chevrons posteriorly. Legs yellow, darker rings on bases and ends of segments. Retrolateral spine on palpal tarsus (Fig. 10A).

GenitaLia. Epigyne strongly sclerotized, especially in the anterior part, with pair of pockets in front of the epigastric fold (Fig. 10A-F; figures show intraspecific variation). Internal structure as in Fig. 10G$\mathrm{H}$, copulatory openings placed in deep atria, small accessory glands connected to spermathecae.

\section{Remark}

One male was found together with the holotype in the same vial, but this specimen is not mentioned in the original description.

Pochytoides securis sp. nov. urn:1sid:zoobank.org:act:008FA360-997C-46A9-A2AB-326CE1BAD9CB

Figs $11-12$

\section{Etymology}

The specific name is Latin for axe and refers to the shape of the anterior lobe of the bulb.

\section{Type material}

\section{Holotype}

GUINEA: गे, Mts Nimba, Zougué valley, near Gbakoré mine camp, $778 \mathrm{~m}$ a.s.l., fogging, young secondary gallery forest, 5 Oct. 2011, Van den Spiegel et al. leg. (MRAC).

\section{Paratypes}

GUINEA: $1 \hat{\jmath}, 1$, together with holotype (MRAC 238 206); $1 \hat{\jmath}, 1$ q, Mts Nimba, grassy area, 1952-1962, M. Lamotte leg. (NHM); 1 क, Mts Nimba, Ziela, 639 m a.s.l., primary forest, in litter, sieving, 15 Feb. 2012, A. Hernard et al. leg. (MRAC 238 729); 1 +, Mts Nimba, Freton, 572 m a.s.l., litter under trees, sieving, 10 Mar. 2012, A. Hernard et al. leg. (MRAC 239 305); 1 q, Mts Nimba, Riolou, secondary forest, beating, 5 Mar. 2012, A. Hernard et al. leg. (MRAC 243 453A); 1 q, Mts Nimba, Seringbara, near camp, secondary forest, beating, 18 Feb. 2012, A. Hernard et al. leg. (MRAC 243 477A); 1 ․ Mts Nimba, Seringbara forest, $606 \mathrm{~m}$ a.s.l., secondary forest, fogging, 13 Mar. 2012, A. Hernard et al. leg. (MRAC 239 635); 1 ㅇ, Mts Nimba, Seringbara, Kpèlyi forest, 601 m a.s.1., secondary forest, litter under trees, sieving, 21 Mar. 2012, A. Hernard et al. leg. (MRAC 239 251).

\section{Differential diagnosis}

The male differs from that of other species in having an unique anterior lobe of the bulb, broadening distally, with a small triangular process on the prolateral edge at mid-length (Fig. 11E). The female is easily recognized from congeners by the unique structure of the epigyne with relatively weakly sclerotized atria and long seminal ducts (Fig. 12A-B).

\section{Description}

\section{Male}

DimEnsions. Cephalothorax: length 2.2-2.3, width 1.7-1.8, height 1.1-1.2. Eye field: length 1.0-1.1, anterior width 1.6-1.7, posterior width 1.4-1.5. Abdomen: length 1.9-2.1, width 1.4-1.5. 
Colour AND BODY. General appearance as in Fig. 11A. Carapace dark brown, black line along edges of carapace, white hairs on slopes and on foveal area. Anterior median eyes lack black rings but encircled by fawn scales, fawn hairs on eye field (Fig. 11B). Clypeus brown. Chelicera with an unusually large promarginal tooth (Fig. 11C). Mouthparts brownish, sternum yellow. Abdomen greyish beige to dark brown, with yellow serrated band medially (Fig. 11A), venter dark with four lines formed by white dots. Spinnerets dark. First pair of legs dark brown, metatarsus and tarsus lighter. Other legs brownish with darker femora. Coxae and trochanters of all legs pale.

Genitalia. Pedipalps brown, cymbium clothed in dense pale hairs. Palpal organ as in Fig. 11D-H, bulb with characteristic wide anterior lobe. Dorsal apophysis slightly broader than in other species.
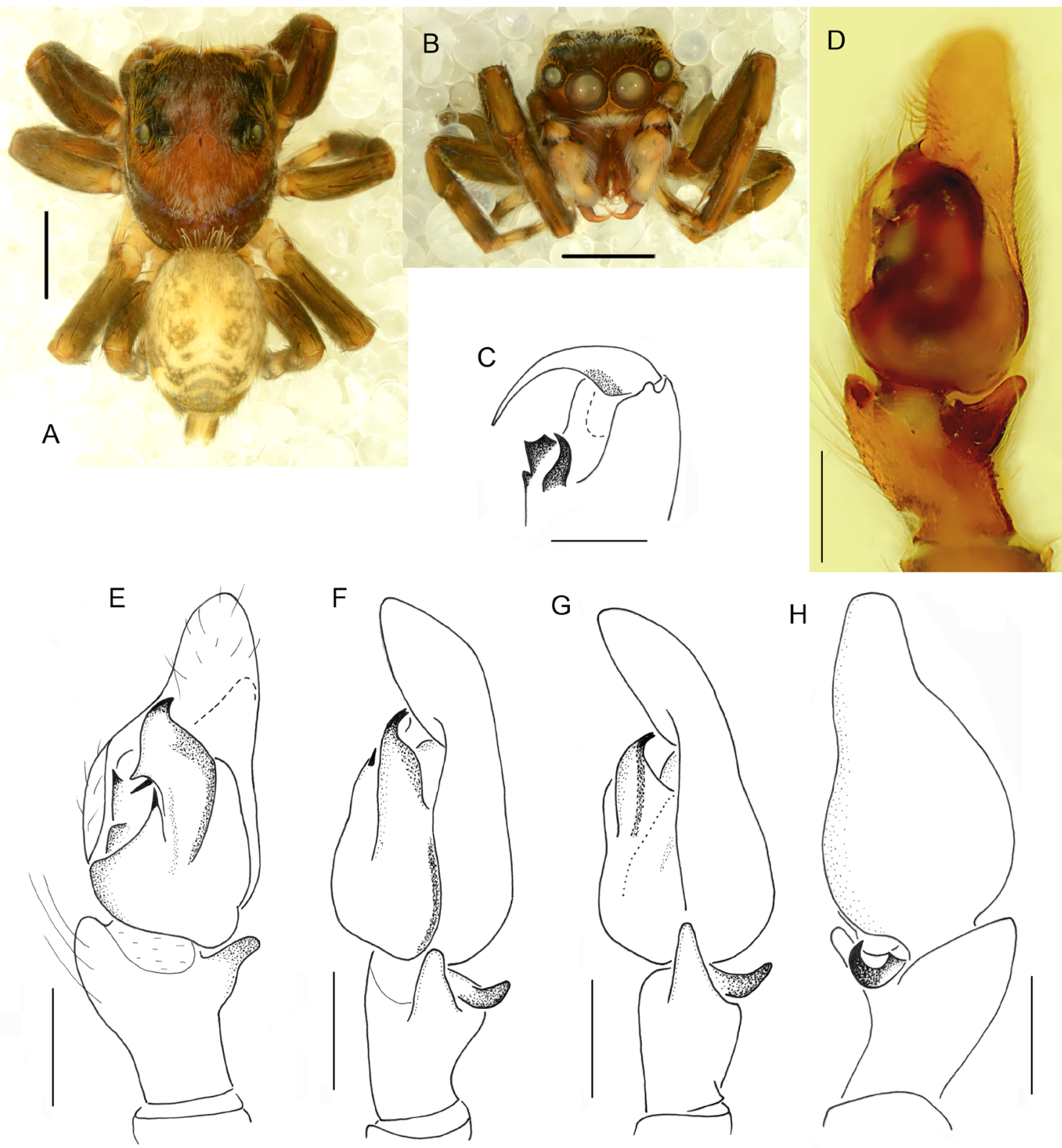

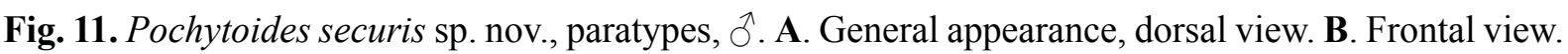
C. Cheliceral dentition. D-H. Palpal organ. D-E. Ventral view. F. Ventroretrolateral view. G. Retrolateral view. H. Dorsal view. Scale bars: A-B $=1.0 \mathrm{~mm}, \mathrm{C}-\mathrm{H}=0.3 \mathrm{~mm}$. 

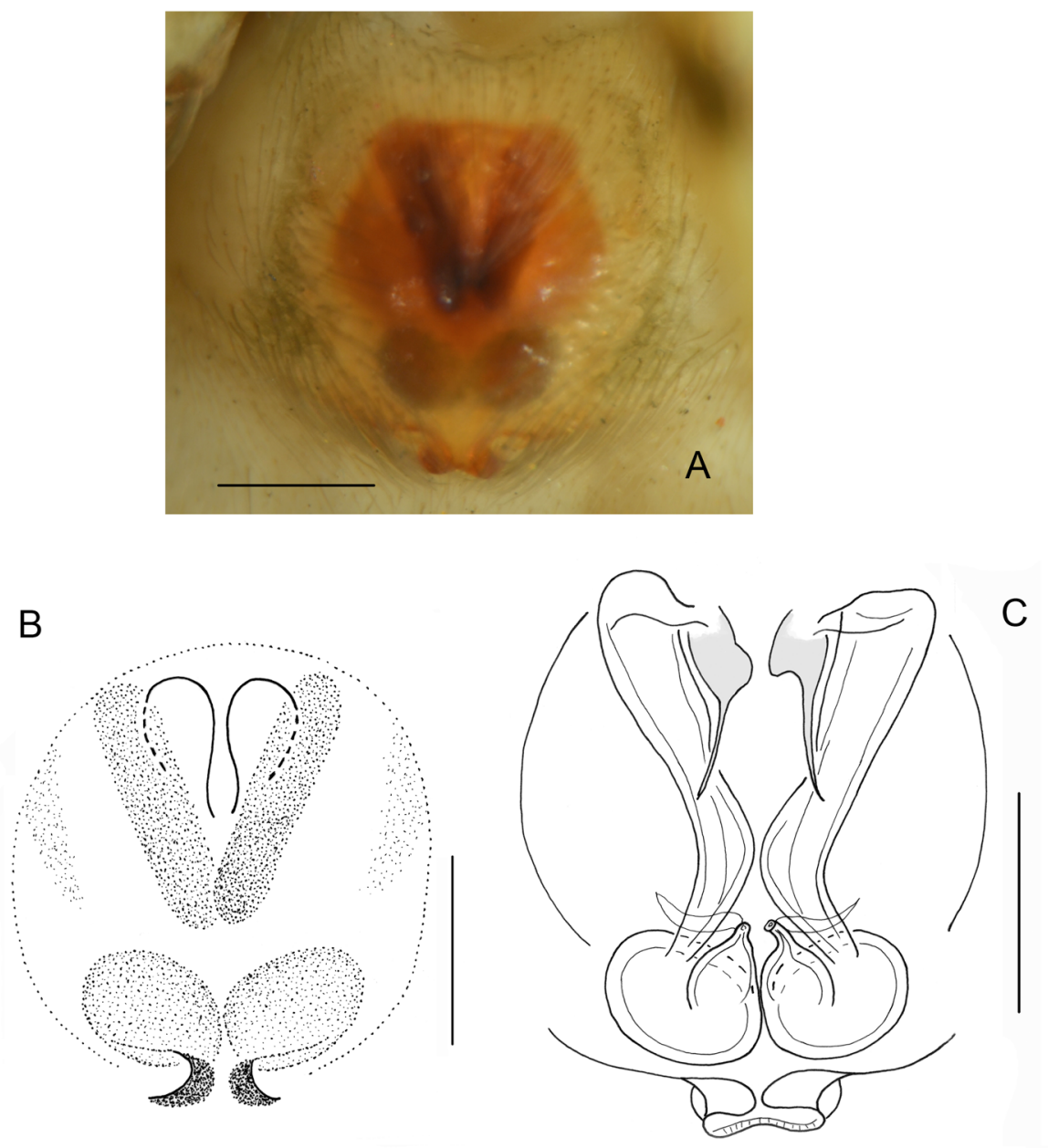

Fig. 12. Pochytoides securis sp. nov., paratypes, + . A-B. Epigyne. C. Internal structure of epigyne. Scale bars: $0.2 \mathrm{~mm}$.

\section{Female}

Dimensions. Cephalothorax: length 1.9-2.0, width 1.5-1.7, height 0.9-1.0. Eye field: length 1.0-1.1, anterior width 1.4-1.5, posterior width 1.3-1.4. Abdomen: length 1.7-2.2, width 1.3-1.6.

Colour And Body. Similar to male, slightly lighter coloured. Anterior median eyes encircled by grey scales, grey hairs on eye field. Abdomen yellowish.

Genitalia. Epigyne rounded, less sclerotized than in other species (Fig. 12A-B). Atria small, weakly sclerotized, copulatory canals long (Fig. 12C).

\section{Pochytoides spiniger sp. nov.}

urn:1sid:zoobank.org:act:6772A649-48A0-41F5-8B92-E37549A6F462

Figs $13-15$

\section{Etymology}

The specific name is Latin, meaning prickly and refers to the presence of spikes at the base of anterior lobe of the bulb. 


\section{Type material}

\section{Holotype}

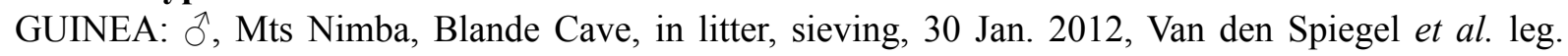
(MRAC 237 858).

\section{Paratypes}

GUINEA: 4 $\widehat{\jmath}, 4$ 우, Mts Nimba, low grassy area, 1952-1962, M. Lamotte leg. (NHM); 1 , Mts Nimba, savanna, 1952-1962, M. Lamotte leg. (NHM); 1 ð, 1 ㅇ, Mts Nimba, Nion, $7^{\circ} 36^{\prime} \mathrm{N}, 8^{\circ} 28^{\prime} \mathrm{W}$, 16 Jun. 1942, M. Lamotte leg. (NHM); 1 +, Mts Nimba, Gbié forest, near Deguelou, 595 m a.s.l., in soil litter, sieving, 18 Mar. 2012, A. Hernard et al. leg. (MRAC 239 149); 1 \&, Mts Nimba, Gbié, Miau
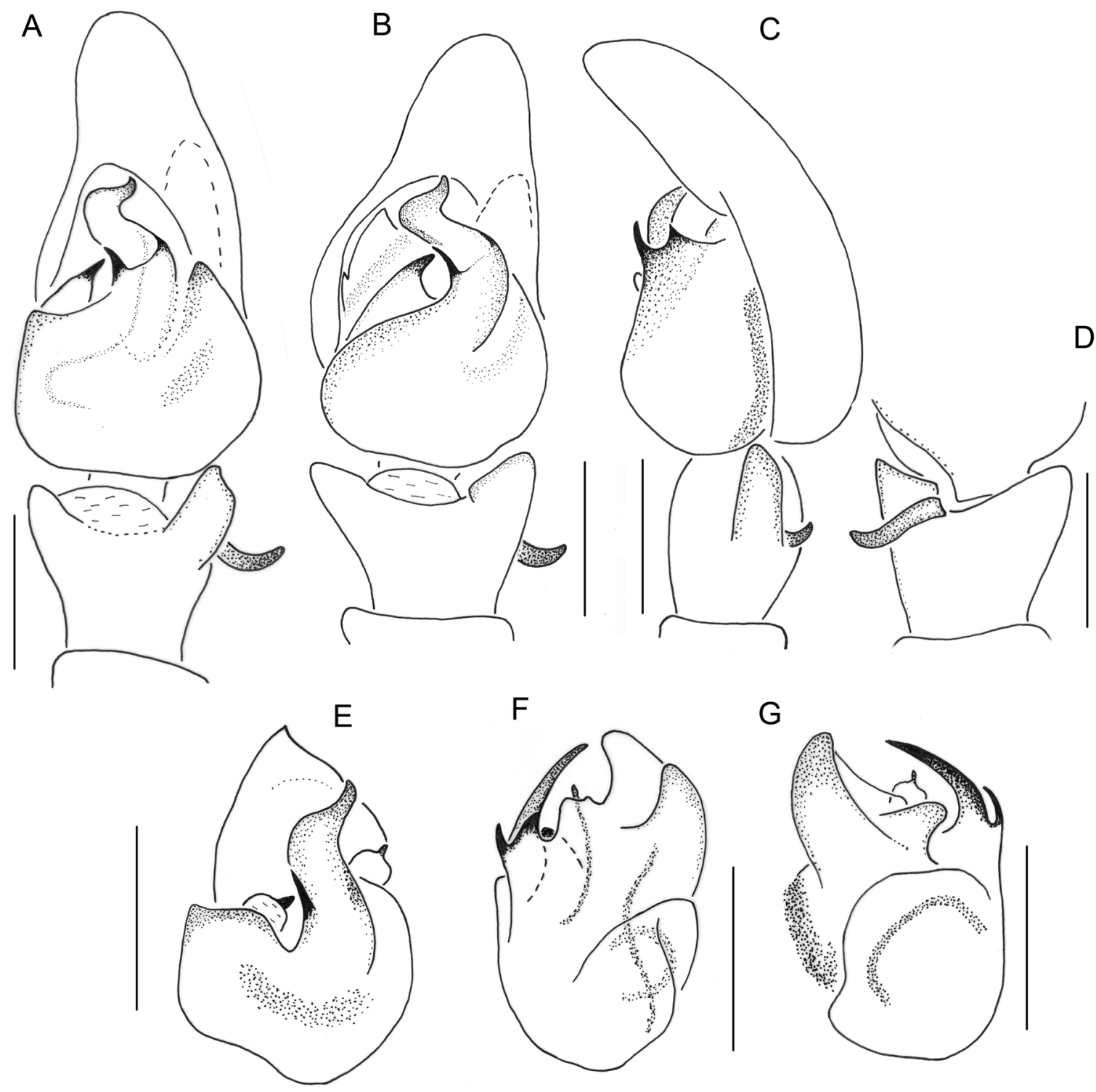

Fig. 13. Pochytoides spiniger sp. nov., paratypes, $\widehat{\jmath}$. A-C. Palpal organ. A. Ventral view. B. Anteroventral view. C. Retrolateral view. D. Palpal apophyses, dorsal view. E-G. Separated bulb. E. Ventral view. F. Retrolateral view. G. Prolateral view. Scale bar $=0.3 \mathrm{~mm}$. 
river, 469 m a.s.l., dry litter, sieving, 16 Mar. 2012, A. Hernard et al. leg. (MRAC 238 706); 1 q, same locality, near river, in litter, sieving, 15 Mar. 2012, A. Hernard et al. leg. (MRAC 238 738A); 2 $\widehat{\partial}$, Mts Nimba, Seringbara, Gouan, $601 \mathrm{~m}$ a.s.l., primary forest, in litter, sieving, 24 Feb. 2012, A. Hernard et al. (MRAC 239 197A); 1 क, Mts Nimba, Seringbara, Gouan forest, near cliffs, in litter, sieving, 2 Oct. 2011, Van den Spiegel and A. Hernard leg. (MRAC 237 986); 2 ठิ

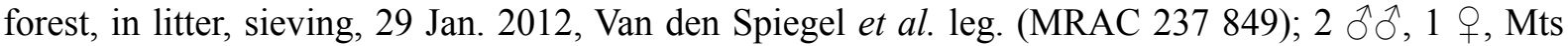
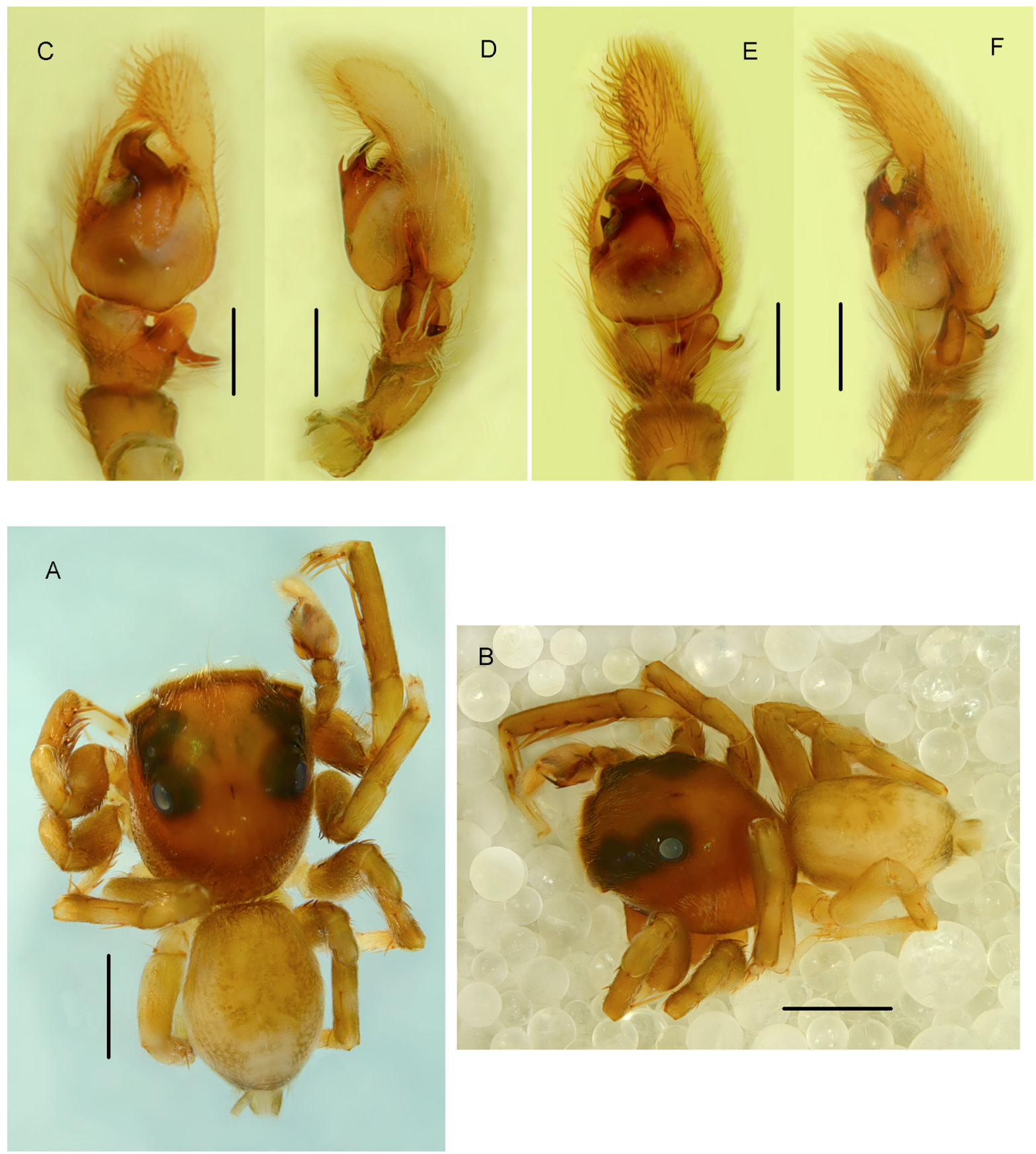

Fig. 14. Pochytoides spiniger sp. nov., paratypes, $\widehat{\sigma}$ (E-F specimen from Nion). A-B. General appearance. A. Dorsal view. B. Dorsolateral view. C-F. Palpal organ. C. Ventral view. D, F. Retrolateral view. E. Ventroretrolateral view. Scale bars: $\mathrm{A}-\mathrm{B}=1.0 \mathrm{~mm}, \mathrm{C}-\mathrm{F}=0.3 \mathrm{~mm}$. 
Nimba, Seringbara forest, in litter, sieving, 13 Mar. 2012, A. Hernard et al. leg. (MRAC 239 034B);

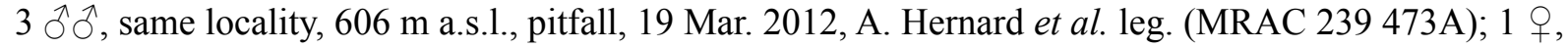
same locality, $722 \mathrm{~m}$ a.s.1., secondary forest, lower vegetation and dead tree trunks, hand collecting, 8 Oct. 2008, Van den Spiegel leg. (MRAC 225 727); 1 §̂, Mts Nimba, Fouenyi forest, $573 \mathrm{~m}$ a.s.1., soil litter, sieving, 1 Mar. 2012, A. Hernard et al. leg. (MRAC 238 838A); 2 우, Mts Nimba, Ga forest, $746 \mathrm{~m}$ a.s.l., primary forest, soil litter, sieving, 6 Mar. 2012, A. Hernard et al. leg. (MRAC 238 759); 1 , , Mts Nimba, Konilokho forest, 473 m a.s.l., pitfall, 16-19 Mar. 2012, A. Hernard et al. leg. (MRAC 239 192A); 1 ㅇ, Mts Nimba, Yeï forest, $601 \mathrm{~m}$ a.s.l., soil litter, sieving, 5 Mar. 2012, A. Hernard et al. leg. (MRAC 238 769); 1 ऊ, Mts Nimba, Gbérémiyi, 469 m a.s.l., primary forest, sieving litter, 10 Mar. 2012, A. Hernard et al. leg. (MRAC 239 282); 1 क, Mts Nimba, station de pompage Zié, $1250 \mathrm{~m}$ a.s.l., forest, sieving litter under high grass, 11 Oct. 2011, Van den Spiegel and A. Hernard leg. (MRAC 237 943); 1 त, same locality, on litter, hand collecting, 3 Feb. 2012, A. Hernard et al. leg. (MRAC $239068)$

\section{Differential diagnosis}

The male resembles that of $P$. lamottei sp. nov. in having a similar sinusoid shape of the anterior lobe of the bulb, but may be recognized by the presence of a short spike at the base of the lobe on its prolateral side (compare Fig. 13C with Fig. 1C). The female is similar to that of P. perezi comb. nov. in having

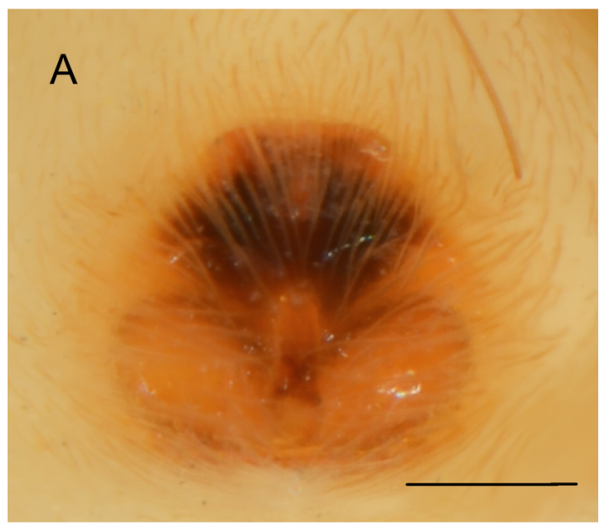

B

C

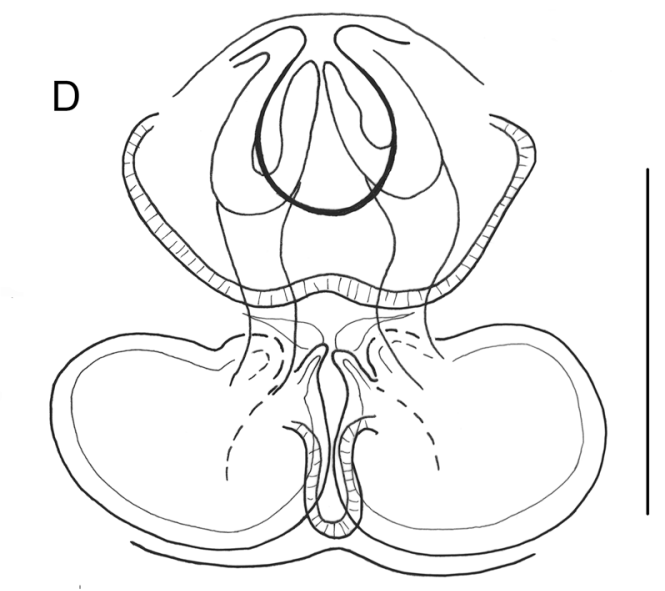

Fig. 15. Pochytoides spiniger sp. nov., paratypes, ․ A-C. Epigyne. D. Internal structure of epigyne. Scale bars: $0.2 \mathrm{~mm}$. 
the epigyne with a $\mathrm{V}$-shaped anterior depression, but may be distinguished by the atrial area narrower than the area occupied by spermathecae (Fig. 15A), quite the opposite to that of $P$. perezi comb. nov. (Fig. 8A-C).

\section{Description}

Male

Dimensions. Cephalothorax: length 1.7-2.2, width 1.4-1.9, height 1.0-1.3. Eye field: length 0.9-1.3, anterior width $1.4-1.7$, posterior width $1.2-1.5$. Abdomen: length $1.5-1.8$, width $1.2-1.5$.

COLOUR AND BODY. General appearance as in Fig. 14A-B. Carapace brown, eye field blackish, anterior median eyes encircled by fawn scales. Some brown bristles near eyes of anterior row, white hairs form wide pale band on slopes of carapace. Clypeus with white hairs. Abdomen dark, greyish brown with light herring-bone pattern becoming in chevrons posteriorly, venter yellowish or greyish. Long brown bristles on anterior edge of abdomen. Anterior spinnerets yellow, posterior grey. Legs yellow with brown rings, femora brownish. Leg hairs and spines brown.

Genitalia. Pedipalps clothed in dense whitish hairs. Palpal organ as in Figs 13A-G, 14 C-F. Retrolateral tibial apophysis blunt and wide, dorsal apophysis narrow perpendicular to retrolateral. Bulb triangular with narrowing anterior lobe. Sharp spike on prolateral side of this lobe at its base (Fig. 13A, C, F), retrolateral margin of the lobe strongly sclerotized basally (Fig. 13B, E).

\section{Female}

DimEnsions. Cephalothorax: length 2.0-2.1, width 1.5-1.8, height 1.1-1.2. Eye field: length 1.1-1.2, anterior width 1.4-1.7, posterior width 1.3-1.5. Abdomen: length 2.1-2.5, width 1.2-1.6.

Colour AND BODY. Similar to male, abdomen slightly clearer, pattern with less contrast. Legs yellow with brownish rings at bases and ends of segments.

GeNITALIA. Epigyne rounded with strongly sclerotized anterior part (Fig. 15A-C). Internal structure as in Fig. 15D, distinctly sclerotized edge around atria, spermathecae relatively large, accessory glands connected visible.

Thiratoscirtus (?) remyi (Berland \& Millot, 1941) comb. nov. Fig. 16

Pochyta (Pochytoides) remyi Berland \& Millot, 1941: 363, fig. 64c.

\section{Type material}

\section{Holotype}

GUINEA: + , cave Tassacouré (locality not identified), [1937, leg. J. Millot] (MNHN) [not examined].

The specimen was examined by Tamás Szüts (pers. com.). It is not a member of Pochytoides and the generic status of the species remains uncertain, requiring further study. The form of the epigyne (Fig. 16) is similar to that of some members of the genus Thiratoscirtus Simon, 1886.

\section{Discussion}

Pochytoides is a small genus, currently containing eight species, which are known only from Guinea. Almost all of them are restricted to the Nimba Mountains. The species from the Nimba Mts are probably syntopic, in some cases specimens of 2-3 species were placed in the same vials, so they were possibly 
collected together. The members of this genus are very similar in body shape, size and colouration. The differences in structure of their genitalia are nonetheless clear, although following the same general pattern. Because these species are closely related and well separated from the other groups, their generic status is postulated based on morphological dissimilarity.

Such a large a number of related species from the Nimba Mts fully supports recognition of this mountain range as an area of exceptional biological richness. The mountains are situated within the Guinean Forests of West Africa biodiversity hotspot, which harbours an especially rich flora and fauna with a high level of endemism (UNESCO World Heritage Centre 2016). In recognition of its unique value, the Nimba Range (jointly $180 \mathrm{~km}^{2}$ ) was declared a Strict Nature Reserve, after Guinea and Côte d'Ivoire became independent. UNESCO proclaimed Mount Nimba a biosphere reserve in 1980, and a World Heritage Site shortly thereafter.

This paper is a contribution to the knowledge of the spider diversity of the Nimba Mts and shows a high species diversity of this poorly known genus of jumping spiders.

\section{Acknowledgements}

I would like to deeply thank Christine Rollard, Anthony Russell-Smith, Arnaud Henrard and Rudy Jocqué for sharing the material for this study. I am also grateful to Christine Rollard for her help with decoding the habitat abbreviations on some labels in M. Lamotte's collection and to Anthony RussellSmith for valuable comments and improving the English.

\section{References}

Berland L. \& Millot J. 1941. Les araignées de l'Afrique occidentale française. I. Les Salticidés. Mémoires du Musée d'Histoire naturelle 12: 297-424.

Bodner M.R. \& Maddison W.P. 2012. The biogeography and age of salticid spider radiations (Araneae: Salticidae). Molecular Phylogenetics and Evolution 65: 213-240.

https://doi.org/10.1016/j.ympev.2012.06.005

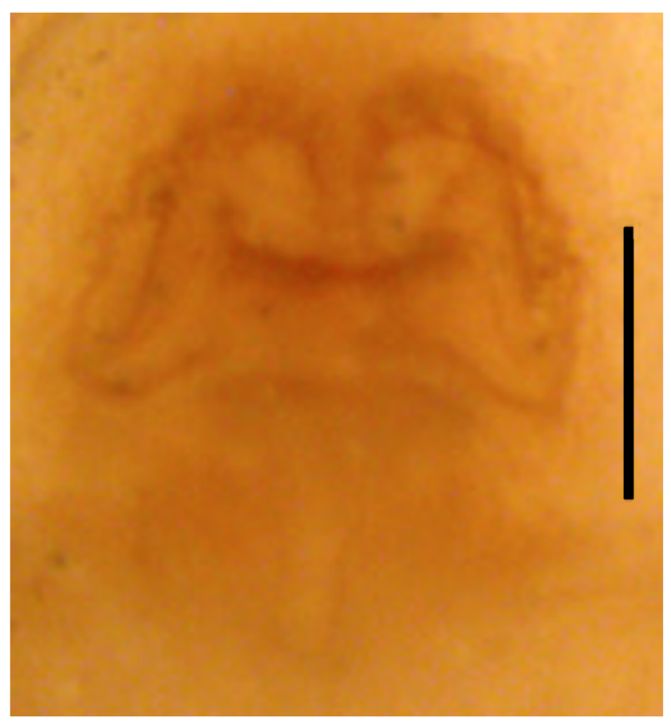

Fig. 16. Holotype of Pochyta remyi Berland \& Millot, 1941, +, epigyne (photo T. Szüts). Scale bar: $0.2 \mathrm{~mm}$. 
Maddison W.P. 2015. A phylogenetic classification of jumping spiders (Araneae: Salticidae). Journal of Arachnology 43: 231-292. https://doi.org/10.1636/arac-43-03-231-292

Metzner H. 1999. Die Springspinnen (Arachnida, Araneae, Salticidae) Griechenlands. Andrias 14: $1-279$.

Rollard Ch. \& Wesołowska W. 2002. Jumping spiders (Araneae, Salticidae) from the Nimba Mountains, Guinea. Zoosystema 24 (2): 283-307.

UNESCO World Heritage Centre. 2016. Mount Nimba Strict Nature Reserve. Available from whc.unesco.org [accessed 23 Feb. 2016].

Manuscript received: 19 July 2017

Manuscript accepted: 22 September 2017

Published on: 26 March 2018

Topic editor: Rudy Jocqué

Desk editor: Pepe Fernández

Printed versions of all papers are also deposited in the libraries of the institutes that are members of the EJT consortium: Muséum national d'Histoire naturelle, Paris, France; Botanic Garden Meise, Belgium; Royal Museum for Central Africa, Tervuren, Belgium; Natural History Museum, London, United Kingdom; Royal Belgian Institute of Natural Sciences, Brussels, Belgium; Natural History Museum of Denmark, Copenhagen, Denmark; Naturalis Biodiversity Center, Leiden, the Netherlands; Museo Nacional de Ciencias Naturales-CSIC, Madrid, Spain; Real Jardín Botánico de Madrid CSIC, Spain. 